\title{
Quantifying Library Engagement: Aligning Library, Institutional, and Student Success Data
}

\section{Rebecca A. Croxton and Anne Cooper Moore}

\begin{abstract}
To determine which engagement factors correlate with student success at a large, public, research university in the southeastern United States, the university library, along with representatives from Academic Affairs, Student Affairs, and other academic and support units across campus are collaborating in the alignment and analysis of student engagement and success data. Findings suggest there is a significant, positive relationship between engagement in library, co-curricular, and extracurricular activities and student success. The model developed for this study is one that is easily transferable to other organizations. These data are being used to develop a repository that enables longitudinal study.
\end{abstract}

\section{Introduction}

Universities frequently call upon academic libraries to document their value when competing for university resources. While libraries track data relating to student engagement, it is challenging to quantify a library's overall contribution to student success by virtue of its role as a service unit. Student success, retention, and graduation rates have become critical issues in higher education, with more than 40 percent of students seeking a four-year degree dropping out within six years. ${ }^{1}$ Tinto's student integration theory posits that students need integration into formal and informal academic and social systems of the university to be successful. ${ }^{2}$ This model holds that engagement in these formal and informal systems strengthens students' academic intentions, goals, and commitment to their institutions, making them more likely to graduate. While higher education institutions are making concerted efforts to retain their students and promote intellectual development, myriad other factors may be at work that significantly impact student success. ${ }^{3}$ Through the lens of the student integration theory, formal engagement with the university may also include the following: 1) library engagement; 2) use of student academic support services; and 3) participation in co- and extracurricular activities.

To assess which engagement factors significantly contribute to student success at a large, public, research university in the southeastern United States, the university library, along with representatives from Academic Affairs, Student Affairs, and other academic support units across campus have agreed to contribute their co-curricular and extracurricular student data to

\footnotetext{
${ }^{*}$ Rebecca A. Croxton is Head of Assessment and Anne Cooper Moore is Dean, both in J. Murrey Atkins Library at the University of North Carolina at Charlotte; email: racroxto@uncc.edu, amoor168@uncc.edu. This project was supported by an Academic Library Impact Research Grant from ACRL's Value of Academic Libraries committee. (C2020 Rebecca A. Croxton and Anne Cooper Moore, Attribution-NonCommercial (https://creativecommons.org/ licenses/by-nc/4.0/) CC BY-NC.
} 
a repository that will enable a multifaceted and evolving longitudinal study. The joint project will allow the library and university leaders to identify key resources, services, and activities within their units that are positively associated with student success. Alignment of student engagement data with measures of student success including GPA, credit-hour completion rates, retention, and graduation rates not only involves identifying key student success and engagement metrics; it also requires careful consideration and protection of student privacy. Key findings from this study, along with the processes involved in aligning and analyzing these data, are outlined in this paper.

As such, the objectives for this study are threefold and align closely with key Priority Areas identified in the Association of College \& Research Libraries' (ACRL) Academic Library Impact Report, which calls for librarians and information professionals to conduct research that will demonstrate library contributions to student learning and success. The first objective of the study, which aligns with ACRL Priority 3, is to "include library data in institutional data collection." In support of this objective, study partners worked closely to balance concerns about how to maintain user privacy with the use of individual student data to measure learning and success outcomes. The second objective, to "quantify the library's impact on student success," aligns with ACRL Priority $4 .{ }^{4}$ The third objective, which follows logically from the first two, is to create a transferable model for aligning and assessing university metrics. To meet these objectives, the university library at the University of North Carolina at Charlotte (UNC Charlotte) is leading an initiative to assess student engagement and its impact on student success by forming partnerships with the university's Office of Institutional Research (IR), the Division of Student Affairs, the University Career Center, the University Center for Academic Excellence (UCAE), the Writing Resources Center, and the University Speaking Center to gather, align, and analyze student engagement and success data.

UNC Charlotte is an urban, research institution with the Carnegie Classification Doctoral Universities: Higher Research Activity. With an enrollment of nearly 30,000 FTE (24,387 undergraduates), UNC Charlotte has the second-largest undergraduate enrollment among the 17 institutions of the University of North Carolina System (as of fall 2018). The university accepts 67 percent of applicants, while incoming classes are 57 percent new freshmen and 43 percent transfers (which means it is a higher transfer student institution). The persistence rate is 82 percent for the first to the second year. ${ }^{5}$ The university emphasizes student participation in research with faculty and in internships in the Charlotte community. Nearly 90 percent of students participate in internships and other research activities. ${ }^{6}$

This paper represents the third iteration of data analysis and reporting related to this project. Findings from the first iteration were shared in a presentation at the Assessment Institute in Indianapolis, Indiana, in October 2018. ${ }^{7}$ The first analysis included student engagement (participation in co-curricular and extracurricular activities as well as use of resources) and success data (cumulative six-year GPA and months-to-graduation) from students who matriculated during the summer or fall of 2012, but it did not include precollege/demographic factors such as high school GPA, ACT/SAT scores, Pell grant awards, incoming transfer credits, and the like. The second iteration of the study involved the same set of student engagement data but also included precollege and demographic factors. Findings from the second round of analysis were presented at the 2018 ARL Library Assessment Conference. ${ }^{8}$ In this third iteration of the study, the data set was expanded three-fold to include undergraduate students who matriculated in the summer or fall of 2012, 2013, and 2014. This data set includes the 
same student engagement and precollege/demographic factors that were used in the previous studies, but this time it uses four-year cumulative GPA and credit-hour completion rates as the dependent variables. The assistant provost for Institutional Research advised the study team to consider credit-hour completion rates as a dependent variable to achieve a more insightful student success measure for a four-year cohort. Findings discussed in this paper were presented at ACRL 2019 conference. ${ }^{9}$ With each iteration of analysis and reporting comes a deeper understanding of the data, maturity in analytical techniques, and new insights through the continual synthesis of findings.

\section{Literature Review}

Throughout the library and information studies literature, findings from a variety of studies have shown that library usage is positively correlated with academic success. ${ }^{10}$ In a study investigating library usage patterns and academic achievement of students enrolled in nearly 200 courses at a single university, findings suggested that students who read more, measured in terms of borrowing books and accessing electronic resources, achieved better grades. ${ }^{11}$ Likewise, findings from a comparison study of 8,701 college students' total library materials checkouts and their graduating GPAs revealed statistically significant, positive correlations between these variables. ${ }^{12}$

Other studies indicated that participation in library instruction is significantly related to students' GPA. ${ }^{13}$ For example, a statistically significant increase in GPA among graduating students who were enrolled in classes that participated in at least one library instruction session $(\mathrm{n}=1,265)$ was demonstrated as compared with students who were enrolled in classes that were not exposed to library instruction $(n=115) .{ }^{14}$ Similarly, in a large scale study of 42,624 students across 12 universities for the academic year 2014-2015, findings revealed that the first-year GPA for students whose courses included information literacy instruction was significantly higher than the GPA of students enrolled in courses that did not include such instruction. ${ }^{15}$

More recently, Soria, Fransen, and Nackerud conducted a series of studies in which they examined the relationships between student academic achievement (GPA, degree completion, retention, and student learning outcomes) and library usage, particularly among first-year students, as documented through several variables (such as online databases access, material borrows, library instruction), along with precollege metrics (for instance, high school GPA, SAT/ ACT scores) and demographic factors (like gender, international student, race, first-generation college student, Pell grant eligibility, college of enrollment, first-year seminar, campus housing, SAT/ACT scores, incoming college credits, and participation in a student academic success program). ${ }^{16}$ The findings from these studies revealed statistically significant regression models that predicted a variety of dependent variables, including students' academic engagement, academic skills, engagement in scholarship, GPA, continued enrollment or graduation, and learning outcomes. ${ }^{17}$ In particular, the results from two of these studies suggested that four types of library services were positively and significantly associated with students' cumulative GPA: database logins, book loans/renewals, electronic journal logins, and use of library workstations. ${ }^{18}$ The model used for Soria, Fransen, and Nackerud's 2013 and 2014 studies was particularly helpful in designing the current study. ${ }^{19}$ Extending these studies further, the present study also includes student engagement variables from other academic support units across the university, High Impact Practice data captured from the university's participation in the National Survey of Stu- 
dent Engagement (NSSE, 2014; 2016; 2018), and student affairs' engagement data, which includes participation in sports clubs and Greek social organizations. Continuing these research efforts and adding additional campus engagement partners to the project enables expansion of the data repository to facilitate a deeper exploration of the relationship between co- and extracurricular activities and student success and to account for more variance in student success by a wider variety of the complex influences at play on university campuses.

The increasing demands placed upon academic libraries to quantify their value in support of student success has created a tension as librarians strive to protect patron privacy as outlined in the ALA Code of Ethics ${ }^{20}$ while needing to analyze student-specific data, to better understand the factors involved in student success. ${ }^{21}$ The movement within higher education institutions to build data repositories to store individual-level, student engagement, and success data is creating an opportunity for libraries to take a leadership role in helping to shape university governance practices to protect student privacy. As such, the NISO Privacy Principles and the Code of Practice for Learning Analytics can serve as useful playbooks for the design of research studies and data repositories, helping to ensure that the use of individual-level student data is performed responsibly, appropriately, and effectively in a way that minimizes adverse impact to students. ${ }^{22}$ In a recently published critical review of the literature about data-handling practices from 54 learning analytics studies in academic libraries, Briney found many examples of inadequate data management practices, including "extended data retention, a broad scope of data collection, insufficient anonymization, lack of informed consent, and sharing of patron-identified data." 23 Briney further recommended that researchers become more transparent in documenting and sharing how they have worked through legal requirements, policies, and practices related to data handling in learning analytics' projects. In this article, the authors describe how they incorporated the NISO Privacy Principles, the Code of Practice for Learning Analytics, and Briney's recommendations as they designed the present study. ${ }^{24}$ This study analyzes the data from a single university to serve as a model to respond to the following research questions.

1. How can libraries connect their data with student outcomes while balancing concerns about user privacy?

2. What effects do libraries have on success outcomes for different types of students?

3. How can libraries contribute to the data collected by other university departments to document student engagement and success?

\section{Methodology}

A two-phase, mixed model was designed to include three data collection strategies. In Phase I, researchers conducted interviews and meetings with university stakeholders to gather insights for Phase II activities. In Phase II, researchers accessed and aligned data sets and conducted statistical analyses (such as ANOVA, Regression) to identify significant factors related to student engagement and success. The independent variables were aligned and integrated with the dependent variables to form a transferable model for longitudinal data analysis. Concurrently across both phases, qualitative data were collected in the form of research notes and meeting minutes related to data handling and student privacy.

\section{Phase I}

Phase I began with a single brainstorming meeting in February 2018 with the key IR and assessment personnel on campus to discuss the justifications for and viability of the project. 
The researchers and specialists discussed how we could align data (independent variables) on individual students from many different campus entities and connect them to the dependent variables held in the student information system (Banner). During the initial meeting, the group created a list of potential partners, established the goals for the project, identified the dependent variables of interest, and agreed on the initial data alignment and de-identification process for the pilot. At this initial meeting, it was agreed that findings would be used in the aggregate not only to align the services, resources, and opportunities offered by study partners, but also to gain a clearer understanding of key engagement points that might be related to student success.

The library agreed to lead the project and then met with each of the recommended partners (the academic support services offered in or near the library building): University Career Center, University Center for Academic Excellence (tutoring, supplemental instruction, peer mentoring, and affiliated services), Writing Resources Center, and the University Speaking Center. These initial partners were selected as they are "academic support" or co-curricular services, mostly formal activities for which student-identifying information was already being collected. Partners also decided to include the most recent results relating to High Impact Practices from the National Survey of Student Engagement (2018) and as many Student Affairs metrics (examples: Greek organization membership and sports club participation) as were available with student-identifying information.

The partners (represented by one or more individuals from each office who were added to the Institutional Review Board [IRB] protocol) agreed to extract data on interactions and participation by student identifier (student ID number or email prefix) from their respective system(s). The researchers held meetings with each individual partner to discuss the project and identify the types of student activities for which they gather student-level data. Overall, gaining buy-in was easy, though there were many conversations about how to protect student privacy, the benefits of the project to each partner, and how the data would be used in the aggregate. The researchers developed a consistent script for the interviews that included explanations for the anticipated topics raised by the partners, particularly regarding protection of student personal information.

The partner representatives (who are listed on the IRB protocol and are the only individuals with access to student personal details) gather email usernames or student ID numbers in the partner's software systems along with the independent variables during the regular conduct of service. The partner representatives are responsible for maintaining the confidentiality of the information contained in their systems according to campus security protocols. On a regular basis (typically at the end of the semester or academic year), the partner representatives extract reports and/or spreadsheets and send them to the assistant provost for Institutional Research via the established protocol approved by the university's IRB and as outlined in the institution's data handling guidelines. The assistant provost loads the data into the Student Information System (SIS) and runs aggregated, de-identified reports upon request and typically for end-of-semester or end-of-year reporting or for specific research projects. Files are password-protected when shared among IRB-approved members of the research team.

The assistant provost for IR creates the connections from the data sets from each partner to a selected hook in the Student Information System (SIS). Only that individual knows what hook (a different identifier from the email username or student ID number provided by the partners) is used to link the records from each partner to the SIS data. 
While the data management and processes for the study were being established, the library took on additional efforts in support of user/student privacy. A Patron Privacy Policy committee was established by the library with an initial charge to conduct a data audit, review library data retention policies, and create a patron privacy statement, which is now publicly available on the library's website. This committee is chaired by the library's Copyright and Licensing Librarian (a JD/MLS) who works closely with the Legal Affairs office of the university to ensure the privacy rights of students and other patrons are protected. In addition to the patron privacy statement, the library also created and adopted language that library employees can use at service desks and in instructional or consultative sessions when fielding students' questions about our collection and usage of student engagement data and personally identifying information (PII), thereby providing a greater level of transparency.

Once it looked like we had sufficient partners to make the project viable, the Office of Research Compliance helped the researchers write the IRB application and ensure everything related to the study and protection of student data was in place. A waiver of disclosure to students, according to FERPA requirements, was approved, as it was not possible to contact each student enrolled from 2012-2013 to 2017-2018 to gain consent to access their records, and the research was being conducted with legitimate educational interest to improve students' chances for academic success. Retention of study data is ongoing while this study is active; the data retention policy will be revisited when the research concludes.

The library's head of assessment, who is the study's principal investigator (PI), gathered the data from the partners once they agreed to sign onto the project with one representative from each partner being added to the IRB Protocol. She aligned the incoming data sets and delivered them to the assistant provost for Institutional Research (IR) who performed a crosswalk from the independent variables to the selected dependent variables. He also connected the data set with as many student demographic measures and indicators of student success (dependent variables) as possible (see table 1). Once the full data set was aligned, the assistant provost for IR removed the identifiers and returned the data set to the library's head of assessment who had agreed to run the aggregated analyses for the partners.

\section{Phase II}

In the first alignment effort for the project, engagement and success data were gathered and aligned at the individual student level from all initial partners (see table 1) for academic years 2012-2013 through 2017-2018, though there are some inconsistencies in the data contributed, as some partners did not have full data sets dating back to 2012. Overall, data from the library, the University Career Center, and the University Center for Academic Excellence were most complete, as these offices provided data for all six years of interest. The University Speaking Center provided data for the 2016-2017 and 2017-2018 academic years, while the Writing Resources Center data included the 2013-2014 to 2017-2018 period. While Student Affairs wanted to participate in the study, they could only provide Greek organization and sports teams/clubs membership for the two most recent academic years. NSSE data were compiled, consolidated, and included in the study for 2014, 2016, and 2018. At this point, there are more than 70,000 individual student records and 375 variables included in the study. The partners plan to provide the same data for enrolled students for each academic year moving forward. The data set will be kept only as long as it is needed to accomplish the goals of the research project and accessed only by the assistant provost for IR in highly secure storage. 


\begin{tabular}{|c|c|c|c|c|c|c|}
\hline \multicolumn{7}{|c|}{$\begin{array}{c}\text { TABLE } 1 \\
\text { Study Variables of Student Activity }\end{array}$} \\
\hline Engagement Variables & Library & $\begin{array}{l}\text { Career } \\
\text { Center }\end{array}$ & $\begin{array}{l}\text { University Center for } \\
\text { Academic Excellence }\end{array}$ & $\begin{array}{l}\text { Writing } \\
\text { Center }\end{array}$ & $\begin{array}{l}\text { Speaking } \\
\text { Center }\end{array}$ & $\begin{array}{l}\text { Student } \\
\text { Affairs }\end{array}$ \\
\hline Individual Consults & $x$ & $x$ & $\mathrm{x}$ & $x$ & $x$ & \\
\hline Workshops & & $x$ & $x$ & $x$ & $x$ & \\
\hline Class Presentations & & $x$ & $x$ & $x$ & $x$ & \\
\hline Career Fairs & & $x$ & & & & \\
\hline Self-assessments & & $x$ & & & & \\
\hline Seminars & & & $x$ & & & \\
\hline Mentoring & & & $x$ & & & \\
\hline Supplemental Instruction & & & $x$ & & & \\
\hline Greek Organization Member & & & & & & $x$ \\
\hline Sports Club Member & & & & & & $x$ \\
\hline NSSE-Total HIPs & & & & & & $x$ \\
\hline Greek Study Hall & $x$ & & & & & \\
\hline $\begin{array}{l}\text { Information Literacy } \\
\text { Instruction }\end{array}$ & $x$ & & & & & \\
\hline Study Rm. Reservations & $x$ & & & & & \\
\hline After-Hours Building Access & $x$ & & & & & \\
\hline Computer Logins & $x$ & & & & & \\
\hline EZ Proxy Access & $x$ & & & & & \\
\hline Book Checkouts & $x$ & & & & & \\
\hline Laptop Checkouts & $x$ & & & & & \\
\hline Other Checkouts & $x$ & & & & & \\
\hline Special Collections Visits & $x$ & & & & & \\
\hline \multicolumn{7}{|c|}{ Office of Institutional Research } \\
\hline \multicolumn{2}{|l|}{ Dependent Variables } & \multicolumn{2}{|c|}{ Demographic Variables } & \multicolumn{3}{|c|}{ Precollege Variables } \\
\hline \multicolumn{2}{|c|}{$\begin{array}{l}\text { - Four-Year Cumulative GPA } \\
\text { - Four-Year Credits Earned/Attempted } \\
\text { Ratio }\end{array}$} & \multicolumn{2}{|c|}{$\begin{array}{l}\text { - Matriculation Year } \\
\text { - Gender } \\
\text { - Year in School } \\
\text { - Original Admit Status } \\
\text { - Pell Award Amount }\end{array}$} & \multicolumn{3}{|c|}{$\begin{array}{l}\text { - Weighted HS GPA } \\
\text { - ACT/SAT Standardized } \\
\text { - Incoming Credits (Transfer, } \\
\text { AP) }\end{array}$} \\
\hline
\end{tabular}

In the first two iterations of data analysis and reporting, the sample of data was composed of student records from undergraduate students who matriculated into the university in summer or fall 2012. The sample of data was expanded for this current, third round of the study to include undergraduate students who matriculated into the university in the summer or fall 2012, 2013, and 2014. This sample was selected to generate a data set that included three times as many student records that could answer questions related to students' engagement with the university throughout a four-year window and to allow for predictions of cumulative GPA and credit-hour completion rates after four years. Credit-hour completion rates were calculated by dividing the total earned credit hours (all credit hours at UNC Charlotte for which a grade of A, B, C, D, or P were entered) by total attempted hours. At UNC Charlotte, 
attempted hours include all hours for which a student enrolled and either (1) earned a passing grade, (2) failed, or (3) withdrew from a course after the drop/add period closed. In all, there were 15,437 viable records for analysis that met the parameters outlined for the study. Of these, 9,417 students were initially admitted to the university as new freshmen and 6,020 were admitted as new transfer students. A comprehensive set of frequency data related to the students' precollege and demographic variables is outlined in table 2 . For some variables, the categorical grouping bins are smaller at the lower engagement thresholds and become more standardized at the mid-to-higher groupings. Creating these smaller groupings at the lower thresholds allowed the researchers to gain deeper insights about the point at which the mean scores for GPA or credits earned/attempted significantly change based on the number of engagements with a particular service, resource, or activity.

While cumulative GPA has been a frequently reported measure of student success for decades, the use of credit-hour (or course) completion rates is becoming increasingly common not only as a measure of student success but also as a way to assess whether students are meeting the satisfactory academic progress thresholds necessary to maintain financial aid eligibility. ${ }^{25}$ In addition, some states, including Tennessee, Ohio, and Indiana, have recently passed legislation that ties higher education funding to factors such as graduation and course completion rates rather than enrollment. ${ }^{26}$

Regression and Analysis of Variance (ANOVA) tests were used to predict the two measures of student success identified for this study, four-year cumulative GPA and credit-hour completion rates. Significance thresholds were limited to $(p<.05)$. Stepwise multiple regression analysis was used, as it allowed the researchers to explore the data for relationships when there was uncertainty as to whether relationships did, in fact, exist. ${ }^{27}$

One-way ANOVAs, a statistical test used to compare mean scores within and between groups, were calculated only for those samples meeting a sample size of at least 30, depending upon the number of groups being analyzed. Group size thresholds were established using $\mathrm{G}^{*}$ Power 3 using an a priori power analysis. ${ }^{28}$ In addition, Levene's test for homogeneity of variance was conducted for all ANOVA tests. Assumptions of homogeneity of variance (Levene's test, $p>.05$ ) were not met for the majority of groups, thus Welch's adjusted ANOVA test, a more robust test that is particularly useful with unequal sample sizes, was used in place of the traditional ANOVA $F$ test. For all significant ANOVAs that included more than two categories for a demographic variable, Games-Howell post hoc analyses were conducted to allow the researchers to identify which particular differences between pairs of means were significant.

\section{Results}

\section{Analysis of Variance}

There were myriad significant ANOVAs related to the two dependent variables. In addition to significance levels, which indicate the likelihood that a relationship between two or more variables occurred by something other than chance (that is to say, $p<.05$ means that there is a 95 percent likelihood a finding is real and not due to chance), effect sizes are also reported using eta squared $\left(\eta_{p}^{2}\right)$. Effect sizes are of particular importance to this study, as they indicate the strength of the relationship between two or more variables on a numeric scale. The majority of effect size findings in this study fell into low $(.01-<.05)$ to medium range $(.05-<$ .10), with one grouping variable falling into the high (.10+) range (total engagements overall). All relevant ANOVA results and associated descriptive statistics are outlined in appendix A. 


\begin{tabular}{|c|c|c|c|}
\hline & Partic & $\begin{array}{l}\text { TABLE } 2 \\
\text { ant Demographics }\end{array}$ & \\
\hline Variable & Aggregate n (\%) & Entered as Freshmen $\mathrm{n}(\%)$ & Entered as Transfer $n(\%)$ \\
\hline Original Admit Status & $15,437(100)$ & $9,417(61.0)$ & $6,020(39.0)$ \\
\hline Matriculation Year (S & mmer/Fall) & & \\
\hline 2012-2013 & $5,072(32.9)$ & $3,047(32.4)$ & $2,025(33.6)$ \\
\hline 2013-2014 & $5,100(33.0)$ & $3,078(32.7)$ & $2,022(33.6)$ \\
\hline 2014-2015 & 5,265 & $3,292(35.0)$ & $1,973(32.8)$ \\
\hline Gender & & & \\
\hline Male & $7,953(51.5)$ & $4,900(52.0)$ & $3,053(50.7)$ \\
\hline Female & $7,455(48.3)$ & $4,510(47.9)$ & $2,945(48.9)$ \\
\hline High School GPA (We & ghted) & & \\
\hline-2.50 & $144(.9)$ & $10(.1)$ & $134(2.2)$ \\
\hline $2.51-3.00$ & $605(3.9)$ & $329(3.5)$ & $276(4.6)$ \\
\hline $3.01-3.50$ & $2,470(16.0)$ & $2,116(22.5)$ & $354(5.9)$ \\
\hline $3.51-4.00$ & $3,884(25.2)$ & $3,574(38.0)$ & $310(5.1)$ \\
\hline $4.01+$ & $3,175(20.6)$ & $2,973(31.6)$ & $202(3.4)$ \\
\hline HS Standardized Test & icore (SAT/ACT) & & \\
\hline $10-15$ & $295(1.9)$ & $12(.1)$ & $283(4.7)$ \\
\hline $16-20$ & $1,872(12.1)$ & $906(9.6)$ & $966(16)$ \\
\hline $21-25$ & $7,077(45.8)$ & $6,204(65.9)$ & $873(14.5)$ \\
\hline $26-30$ & $1,966(12.7)$ & $1,678(17.8)$ & $288(4.8)$ \\
\hline $31+$ & $219(1.4)$ & 179 (1.9) & $40(.7)$ \\
\hline Incoming Credits (Tra & isfer, AP, etc.) & & \\
\hline 0 & $5,062(32.8)$ & $5,041(53.5)$ & $21(.3)$ \\
\hline $1-9$ & $2,592(16.8)$ & $2,550(27.1)$ & $42(.7)$ \\
\hline $10-24$ & $1,461(9.5)$ & $1,138(12.1)$ & $323(5.4)$ \\
\hline $25-39$ & 1,592 (10.3) & $303(3.2)$ & $1,289(21.4)$ \\
\hline $40-59$ & $1,652(10.7)$ & $148(1.6)$ & $1,504(2.5)$ \\
\hline $60+$ & 3,078 (19.9) & $237(2.5)$ & 2,841 (47.2) \\
\hline Pell Recipient & & & \\
\hline Yes & 7,264 (47.1) & $3,888(41.3)$ & $3,376(56.1)$ \\
\hline No & $8,173(52.9)$ & $5,529(58.7)$ & 2,644 (43.9) \\
\hline Sports Club Members & & & \\
\hline Yes & $45(5.5)$ & $688(7.3)$ & $157(2.6)$ \\
\hline No & $14,592(94.5)$ & $8,729(92.7)$ & $5,863(97.4)$ \\
\hline Greek Organization $n$ & embership & & \\
\hline Yes & 1,638 (10.6) & $1,429(15.2)$ & $209(3.5)$ \\
\hline No & $13,799(89.4)$ & 7,988 (84.8) & $5,811(96.5)$ \\
\hline Total High Impact Pra & tices & & \\
\hline 0 & $14,923(96.7)$ & $9,104(96.7)$ & $5,819(96.7)$ \\
\hline $1-2$ & $269(1.7)$ & $137(1.5)$ & $132(2.0)$ \\
\hline $3-6$ & $245(1.6)$ & $176(1.9)$ & $69(1.1)$ \\
\hline
\end{tabular}




\section{Four-Year Cumulative GPA}

Particularly noteworthy among the ANOVAs are findings that suggest four-year cumulative GPA differs significantly in the aggregate depending upon the total number of engagements with university co-curricular and extracurricular services, with a moderate effect size as illustrated in Figure 1 (Welch's $F_{(5,4532.268)}=140.249, p<.01, \eta_{p}{ }^{2}=.06$ ). Even stronger findings were revealed when the test was run for the freshmen matriculants subset (Welch's $F_{(5,1519.604)}=145.382$, $\left.p<.001, \eta_{p}{ }^{2}=.10\right)$. ANOVA findings for students who matriculated as transfers were also significant, though with a small effect (Welch's $\left.F_{(5,2028.277)}=18.294, p<.001, \eta_{p}{ }^{2}=.02\right)$. Post-hoc analysis revealed that students who engaged with the participating units in this study less than 10 times earned significantly lower GPAs than all others.
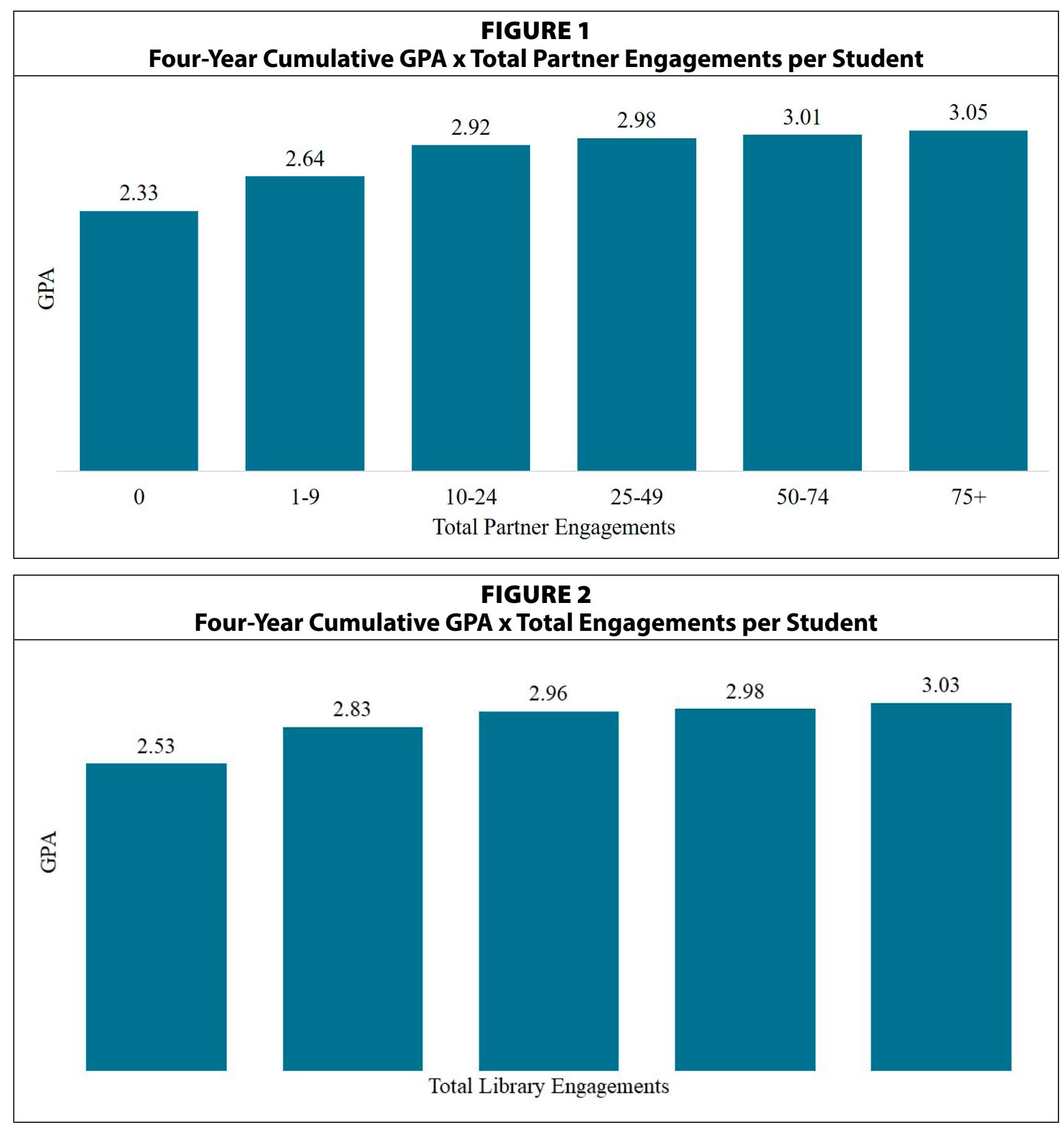
When analyzed by specific partner, significantly higher four-year cumulative GPAs were indicated for students who engaged more frequently with the University Career Center $\left(\right.$ Welch's $\left.F_{(4,952.23)}=315.29, p<.01, \eta_{p}^{2}=.06\right)$, the University Center for Academic Excellence (Welch's $F_{(4,3580.67)}=71.482, p<.001, \eta_{p}{ }^{2}=.01$ ), the library (Welch's $F_{(4,6910.978)}=151.417, p<.001, \eta_{p}{ }^{2}=$ $.05)$, and the Writing Resources Center (Welch's $F_{(2,1379.898)}=242.059, p<.001, \eta_{p}{ }^{2}=.02$ ) in the aggregate, for students who matriculated as new freshmen, and for those who matriculated as transfer students. Figure 2 illustrates the significant differences between total library engagements per student and four-year cumulative GPA. All total library engagement groupings were significantly different from each other, with the exception of the 10-24 and 25-74 groups. Results relating to the University Speaking Center are not included as the sample sizes were too small to be reliable. Overall, ANOVA effect sizes for four-year cumulative GPAs for partner engagements largely fell into the low range, with the exception of the University Career Center and the library, which fell into the medium range for both the aggregate and for new freshman.

Finally, when analyzed by specific library activities, there were many significant and noteworthy findings with respect to four-year cumulative GPA not only in the aggregate, but for students who matriculated as new freshmen and new transfers. Summary results for the aggregate are outlined in table 3. Further details relating to the aggregate, new freshmen, and new transfer students are available in appendix A, table A.1.

\begin{tabular}{|l|l|c|c|}
\hline \multicolumn{4}{|c|}{ TABLE 3 } \\
\multicolumn{4}{|c|}{ Library Activities and Four-Year Cumulative GPA: Significant ANOVAs* } \\
\hline Library Activity & $\begin{array}{l}\text { Welch's } \\
\text { (F) }\end{array}$ & $\begin{array}{l}\text { Significance } \\
\text { (p) }\end{array}$ & $\begin{array}{l}\text { Effect } \\
\text { (np2) }\end{array}$ \\
\hline Logins to library resources via EZ Proxy & 225.047 & $<.001$ & .05 \\
\hline Participation in library instruction & 204.046 & $<.001$ & .03 \\
\hline Study room reservations & 334.920 & $<.010$ & .05 \\
\hline Checkouts of library books & 114.488 & $<.001$ & .03 \\
\hline Logins to library computers & 081.265 & $<.010$ & .02 \\
\hline Checkouts of library laptops & 041.376 & $<.001$ & .01 \\
\hline $\begin{array}{l}\text { Checkouts of other library materials (examples: DVDs, calculators, } \\
\text { equipment) }\end{array}$ & 046.661 & $<.001$ & .01 \\
\hline${ }^{*}$ Aggregate findings reported. & & & \\
\hline
\end{tabular}

ANOVA results also revealed that four-year cumulative GPA differed significantly depending upon the number of High-Impact Practices a student participated in, as reported on the NSSE, not only for the aggregate (Welch's $F_{(2,381.204)}=410.376, p<.01, \eta_{p}{ }^{2}=.02$ ), but also for students who matriculated as new freshmen (Welch's $F_{(2,227.67)}=247.224, p<.01, \eta_{p}^{2}=.02$ ) and new transfers (Welch's $F_{(2,131.991)}=160.82, p<.01, \eta_{p}{ }^{2}=.01$ ). Similar results were noted for students who participated in Greek organizations and sports clubs. In other words, students who participated in a greater number of High-Impact Practices or who were involved in campus Greek life or sports clubs had significantly higher GPAs than those who did not participate in these types of activities. (See appendix A, table A.1.) 


\section{Four-Year Credit-Hour Completion Rates}

ANOVA tests were also conducted for all categorical variables to determine group differences related to credit-hour completion rates. These results largely mirrored those noted for the four-year cumulative GPA, with myriad significant and meaningful findings. Particularly noteworthy among the findings were the results relating to total engagements overall (Welch's $\left.F_{(5,4036.026)}=103.323, p<.001, \eta_{p}{ }^{2}=.05\right)$, which revealed that students who engaged more frequently with any of the partners achieved significantly higher credit-hour completion rates than other students (see figure 3). Likewise, significant ANOVAs with medium effect sizes were also noted based upon the number of engagements with the University Career Center (freshmen subset: Welch's $F_{(4,634.782)}=204.711, p<.001, \eta_{p}{ }^{2}=.07$ ) and the library (freshmen subset: Welch's $\left.F_{(4,3982.122)}=92.327, p<.001, \eta_{p}^{2}=.06\right)$.

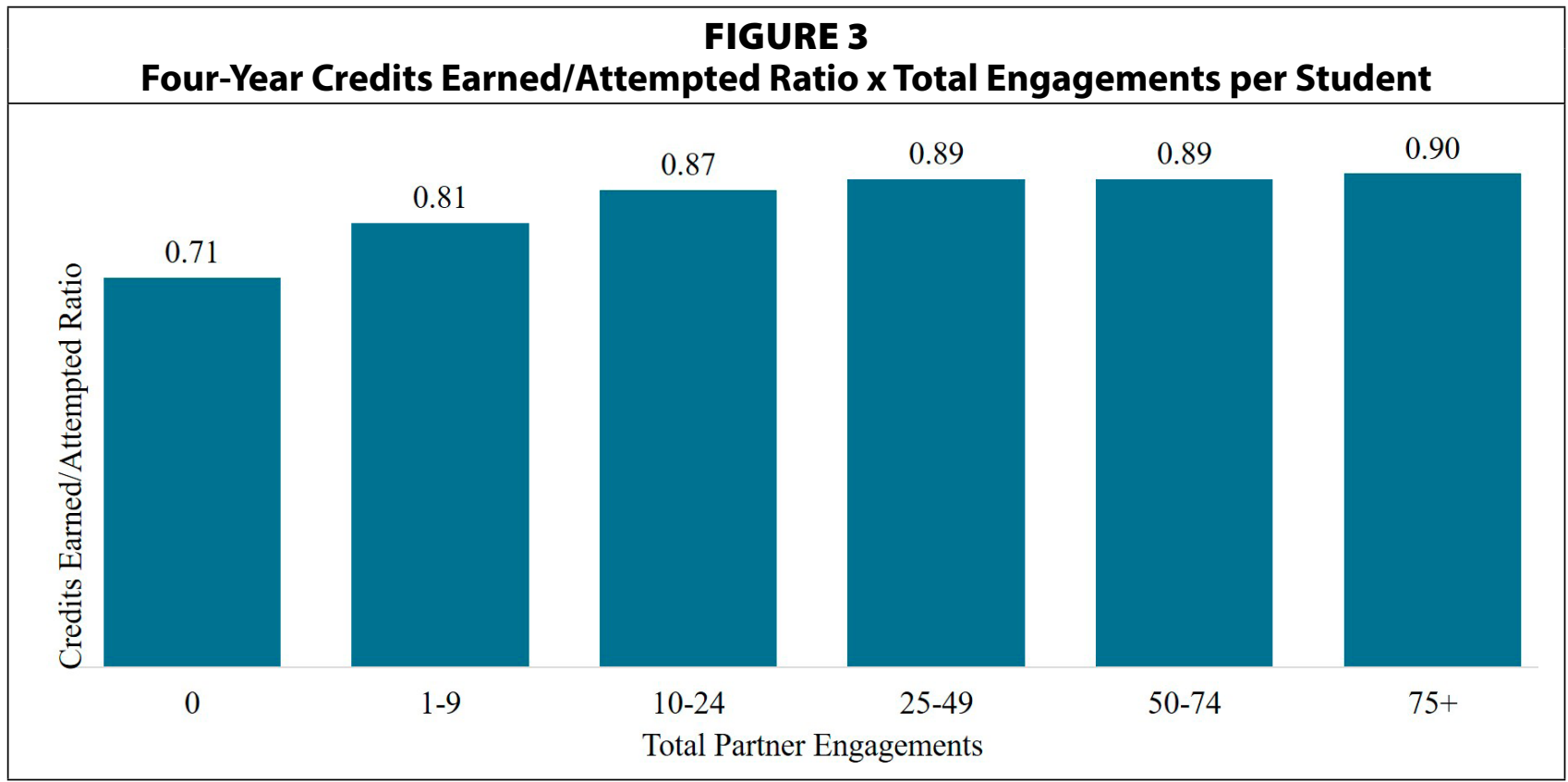

\section{Stepwise Regression}

Stepwise Regression tests revealed numerous statistically significant models that predicted four-year cumulative GPA and credit-hour completion rates, not only for the aggregate, but also for students who matriculated either as freshmen or transfer students. For each of the dependent variables, separate regression analyses were run to include the following:

1. Total of all engagements across all partners;

2. Total engagements $X$ partner;

3. Total engagements $X$ specific partner activities;

4. All specific partner activities $X$ precollege/demographic factors, such as the following:

a. Weighted high school GPA;

b. ACT/SAT scores (standardized);

c. Incoming transfer credits (including AP credits);

d. Pell grant-total awarded;

e. Greek organization and sports clubs/team participation; and

f. High-Impact Practices (internships, study abroad, learning community, research with faculty, culminating senior experience, and other practices). 
5. Total library engagements;

6. Engagements in specific library activities (including study room reservations, library instruction, computer logins, book checkouts, and other activities);

7. Engagements in specific library activities $\mathrm{X}$ precollege/demographic factors, such as the following:

a. Weighted high school GPA;

b. ACT/SAT scores (standardized);

c. Incoming transfer credits (including AP credits);

d. Pell grant-total awarded;

e. Greek organization and sports clubs/team participation; and

f. High-Impact Practices (internships, study abroad, learning community, research with faculty, culminating senior experience, and other practices).

Of these 42 regression tests, all were statistically significant $(p<.05)$.

\section{Four-Year Cumulative GPA}

Overall, the models that included only university partner data (not precollege or demographic factors) though statistically significant, predicted, at most, 8.7 percent of the variance in fouryear cumulative GPA for new freshmen $\left(F_{(6,9396)}=149.404, p<.001\right), 6.3$ percent for the aggregate $\left(F_{(6,15387)}=173.660, p<.001\right)$, and 3.5 percent for new transfer students $\left(F_{(4,5986)}=53.818, p<.001\right)$. Adding in precollege/demographic variables and specific partner activities resulted in noticeably higher ability to predict variances in four-year cumulative GPA. Overall, the model that included all partner activities along with precollege/demographic factors was the strongest $\left(F_{(17.8590)}=144.086, p<.001\right)$ and explained 22.2 percent of the variance in four-year cumulative GPA for freshmen matriculants, 21.7 percent for the aggregate $\left(F_{(17,9652)}=157.089, p<.001\right)$, and 16.6 percent for new transfers $\left(F_{(8,1053)}=26.213, p<.001\right)$. In a separate regression analysis that included only specific library activities (no precollege or demographic factors), the model was able to explain 6.6 percent of the variance in four-year cumulative GPA for freshmen matriculants $\left(F_{(5,9397)}=133.113, p<.001\right), 5.6$ percent for the aggregate $\left(F_{(5,15388)}=180.844, p<.001\right)$ and 3.8 percent for new transfers $\left(F_{(4,5986)}=58,835, p<.001\right)$. See appendix B, table B.1 for further details and a listing of significant variables for regression analyses related to four-year GPA.

\section{Four-Year Credit-Hour Completion Rates}

Similar to the models used to predict four-year cumulative GPA, models that included precollege and demographic factors had greater ability to explain variance in the four-year credit-hour completion rates (see appendix B, table B.2). It should be noted, however, that a statistically significant model using only partner engagement data (no precollege or demographic factors) was able to explain 8.5 percent of the variance for the new freshman subset $\left(F_{(12,8910)}=68.579, p<.001\right)$. This model suggests that engagement with specific services offered by the University Career Center, the library, the University Center for Academic Excellence, the Writing Resources Center, High Impact Practices, and Greek organizations is positively associated with higher credit-hour completion rates.

When precollege/demographic factors were added into the regression analysis that included specific partner activities, the model was able to predict 12.4 percent of the variance for the freshmen matriculant subset $\left(F_{(16,8146)}=72.181, p<.001\right), 11.9$ percent for the aggregate $\left(F_{(14,9145)}=88.005, p<.001\right)$, and 7.5 percent for the transfer student subset $\left(F_{(6,990)}=13.378, p<\right.$ 
.001) (see appendix B, table B.1). In a separate regression analysis that included only specific library activities, the regression equation was able to predict 3.5 percent of the variance in four-year credit-hour completion rates $\left(F_{(5,9397)}=63.728, p<.001\right)$ for the freshmen subset, with similar findings for the aggregate $\left(F_{(5,14524)}=93.012, p<.001, R^{2}=.031\right)$ and the transfer subset $\left(F_{(4,5602)}=30.652, p<.001, R^{2}=.021\right)$.

While the significant findings from the regression analyses conducted to explain variance in four-year credit-hour completion rates are noteworthy, the regression equations relating to four-year cumulative GPA had slightly greater predictive power. Including all engagement metrics and precollege/demographic factors into a regression equation explained 22.2 percent of the variance in four-year cumulative GPA, while the same factors explained 12.4 percent of the variance in the four-year credit-hour completion rates among the freshmen matriculants subset.

\section{Discussion}

\section{Connecting Library Data with Student Outcomes}

As libraries work to balance the tenuous relationship between quantifying their value by using individual-level student data and protecting student privacy, it is essential that they first lay the groundwork for how best to gather, manage, and use engagement data in a way that minimizes adverse risk to students. Forming relationships and having conversations with the university's office of research compliance and the office of institutional research from project inception is a critical first step. The NISO Privacy Principles and the Code of Practice for Learning Analytics are terrific resources that can serve as valuable playbooks when preparing a research study or building a data repository using individual-level data. ${ }^{29}$

In working through patron privacy concerns related to library data, it is critical to ensure a process is in place to de-identify student engagement data once initially aligned, with only the partner representative from the office of institutional research having access to identifiable information. Establishing a library patron privacy policy that wrestled with some of the early questions of what data the library collects and how it should be handled was also vital in laying the groundwork for the study. For example, through working with the library's patron privacy policy committee and library administration, it was agreed upon that tallying the number of library book checkouts per each student in a given time frame, rather than documenting the titles of these items, was acceptable for this study as long as privacy protections were in place as outlined in the IRB protocol.

\section{Quantifying the Relationship between Library Engagement and Student Success}

Study findings suggest that engagement with various university resources, including the library, is significantly and positively associated with student success across multiple analysis techniques. Most noteworthy among library-specific findings, students who logged in (for example, authenticated via EZ Proxy) to access online library resources, reserved library study rooms, participated in library instruction, and checked out library books achieved higher GPAs and credit-hour completion rates than those who did not. As such, libraries can promote library instruction opportunities and resources to faculty and students in support of student success, using quantifiable findings to support their efforts.

In addition to demonstrating the relationship between student success and library use, study findings revealed other key areas of engagement for students, including those associ- 
ated with the University Career Center, the University Center for Academic Excellence, the Writing Resources Center, and the University Speaking Center. These categories of engagement, along with participation in Greek organizations, sports clubs, and High-Impact Practices, all lend support to Tinto's student integration theory, which suggests that academic, co-curricular, and extracurricular engagements may help to increase the chances of student success and the likelihood of graduation. ${ }^{30}$ Based upon this theory, the types of engagements included in this study might all be considered formal, as they are provided, organized, or sponsored by the university in an official way (for example: formal academic engagements = library, career center, writing center; formal social opportunities = Greek life, universitysponsored sports clubs). As such, the findings from this study suggest that engagement in the formal co-curricular and extracurricular systems of the university, those things that take place outside the academic classroom, play an important role in student success. Library and university leaders can use these findings to identify key resources, services, and activities within their units that are positively associated with student success. Tinto's model may not apply as effectively to students such as those from minority populations, return-to-college students, or transfer students who have family, work, or other obligations that require them to remain more committed to their home community or family rather than to engage fully in campus opportunities.

\section{Connecting Library and Other University Departments' Data to Document Student Engagement and Success}

Aligning co-curricular and extracurricular student engagement metrics with measures of student success can provide powerful insights for universities as they seek ways to create stronger ties to the university and encourage students to remain (be retained) and complete their academic goals (graduate). Creating a central data repository with the right structure and rapid updates increases the ability to understand what activities and services have a positive influence on student success. The repository should include not only measures of student engagement and success, but also precollege and demographic variables, as the disaggregation of data is necessary to understand particular categories of students. While the analysis for this study involved disaggregating data according to original admission status (freshman or transfer), it is only a first step in understanding our university population. The model developed for this study, which involved inviting other university constituents to form a partnership, share ideas, make mutually beneficial decisions, outline responsibilities, work together to identify key metrics, and collaborate to align and analyze complex student data is one that is easily transferable to other types of higher education institutions, including both two-year and four-year institutions, and with other types of student populations including graduate students and early college/pipeline programs for high school students. The power of the model to explain our impact on student success will intensify as new partners are identified and brought into the study.

\section{Study Limitations}

Although every attempt was made to conduct a thorough exploration of the co-curricular and extracurricular factors relating to undergraduate students' engagement and success, the study was subject to numerous limitations. The reliance on GPA and course completion rates as a reflection of student success is a limitation that results from the challenge of measuring actual 
learning in human beings. Some limitations relate to the data set, which had many missing or inconsistent variables that had to be ignored or imputed. Transitioning from the full data set to the portion with the most complete and reliable data actually improved our ability to explain variations in the data, despite the smaller number of records. Moving forward, the current partners now have a clearer understanding of the categories of data they need to collect and methods for doing so that will make future alignment and analysis much easier and more accurate.

Through this analysis, the researchers realized the advantage of recruiting additional partners, particularly those departments or units directly responsible for managing the HighImpact Practices across the university, including study abroad, undergraduate research, learning communities, internships, and more. The most significant limitation to the study was relying upon self-report data from the NSSE surveys related to High-Impact Practices, since completion of NSSE is voluntary and subject to significant inaccuracies inherent in selfreporting. With this third iteration of data analysis and synthesis, the researchers continued to develop a deeper understanding of the data set and maturity in analyzing the data to tell the most accurate story of how student engagement and success align. As new partners are identified and additional student engagement data are ingested into the repository, it is anticipated that the ANOVA effect sizes and the ability to explain more variance in the dependent variables through regression analyses will continue to increase.

Returning to suggestions for data handling outlined by NISO, Sclater and Bailey, and Briney, there is continued room for improvement in the present study. ${ }^{31}$ In particular, study partners have not yet identified ways by which we can become more transparent to our students about the research we are conducting and the continuous improvement efforts that involve data about them; this will be a topic of discussion among study partners moving forward. Providing students with access to their own data and options for them to opt out of the study are additional areas to be addressed in future iterations of this research.

\section{Conclusions}

The study demonstrates that engagement in library, co-curricular, and extracurricular activities has a positive relationship to student success as measured by four-year cumulative GPA and credit-hour completion rates. Future studies will examine data from additional partners while emphasizing more consistent gathering of activity metrics, incorporating other demographic and precollege factors (such as race, age, student major, resident/commuter status, first-generation status, international students, and other factors), and comparing pre-existing and activity variables to other student success measures. With a greater variety and accuracy of data, we hope to achieve a deeper understanding of the relationship between library use and other aspects of student life and student success and graduation.

The study represents one of the first efforts documented in the library and information studies literature in which the library has taken the lead in developing a transferable model for aligning and assessing university student activity and success metrics to quantify the value of the academic library. Too often, we are not aware of what other units across our campuses are doing in support of our mutual goals to promote student learning, success, and graduation. By building relationships and collaborating on the development of an institutional repository of student engagement and success data, campus units may find themselves less focused on competing for valuable campus resources and more focused on working together for the success of our students. 


\section{APPENDIX A. ANOVAs and Descriptive Statistics}

\begin{tabular}{|c|c|c|c|c|c|c|}
\hline \multicolumn{7}{|c|}{$\begin{array}{c}\text { TABLE A.1 } \\
\text { Four-Year Cumulative GPA }\end{array}$} \\
\hline $\begin{array}{l}\text { Independent } \\
\text { Variables } \\
\end{array}$ & $\mathbf{F}$ & df & $\begin{array}{l}\text { Sig. } \\
(p)\end{array}$ & $\begin{array}{l}\text { Effect } \\
\left(\mathbf{n}_{p}^{2}\right)\end{array}$ & \begin{tabular}{|l} 
Post Hoc \\
Sig. Results*
\end{tabular} & \begin{tabular}{|l} 
Descriptives \\
(Group: N, Mean, SD)
\end{tabular} \\
\hline \multicolumn{7}{|c|}{ Total Engagements Overall } \\
\hline Aggregate & 140.249 & $5,4532.268$ & $<.01$ & .06 & $\begin{array}{l}1-9>0 \\
10-24>0 \\
10-24>1-9 \\
25-49>0 \\
25-49> \\
10-24 \\
50-74>0 \\
50-74>1-9 \\
50-74> \\
10-24 \\
75+>0 \\
75+>1-9 \\
75+>10-24 \\
75+>25-49\end{array}$ & $\begin{array}{l}0: 848,2.33,1.42 \\
1-9: 4,696,2.64,0.96 \\
10-24: 3,694,2.92,0.70 \\
25-49: 2,892,2.98,0.61 \\
50-74: 1,261,3.01,0.59 \\
75+: 2,003,3.05,0.56\end{array}$ \\
\hline New Freshmen & 145.382 & $5,1519.604$ & $<.001$ & .10 & $\begin{array}{l}1-9>0 \\
10-24>0 \\
10-24>1-9 \\
25-49>0 \\
50-74>0 \\
50-74>1-9 \\
50-74> \\
10-24 \\
75+>0 \\
75+>1-9 \\
75+>10-24 \\
75+>25-49\end{array}$ & $\begin{array}{l}0: 180,1.97,1.28 \\
1-9: 2,631,2.58,0.95 \\
10-24: 2,445,2.96,0.67 \\
25-49: 1,974,3.04,0.58 \\
50-74: 857,3.07,0.56 \\
75+: 1,316,3.13,0.53\end{array}$ \\
\hline New Transfers & 18.294 & $5,2028.277$ & $<.001$ & .02 & $\begin{array}{l}1-9>0 \\
10-24>0 \\
10-24>1-9 \\
25-49>0 \\
25-49>1-9 \\
50-74>0 \\
50-74>1-9 \\
75+>0 \\
75+>1-9 \\
\end{array}$ & $\begin{array}{l}0: 668,2.42,1.45 \\
\text { 1-9: } 2,065,2.72,0.98 \\
10-24: 1,249,2.84,0.75 \\
25-49: 918,2.84,0.66 \\
50-74: 404,2.90,0.61 \\
75+: 687,2.89,0.59\end{array}$ \\
\hline
\end{tabular}




\begin{tabular}{|c|c|c|c|c|c|c|}
\hline \multicolumn{7}{|c|}{ University Career Center } \\
\hline Aggregate & 315.291 & $4,952.23$ & $<.01$ & .06 & $\begin{array}{l}1-2>0 \\
3-5>0 \\
3-5>1-2 \\
6-10>0 \\
6-10>1-2 \\
6-10>3-5 \\
11+>0 \\
11+>1-2 \\
11+3-5\end{array}$ & $\begin{array}{l}0: 7,588,2.64,0.96 \\
1-2: 4,735,2.95,0.66 \\
3-5: 2,214,3.10,0.55 \\
6-10: 717,3.22,0.46 \\
11+: 140,3.24,0.46\end{array}$ \\
\hline New Freshmen & 258.954 & $4,597.348$ & $<.01$ & .09 & $\begin{array}{l}1-2>0 \\
3-5>0 \\
3-5>1-2 \\
6-10>0 \\
6-10>1-2 \\
6-10>3-5 \\
11+>0 \\
11+>1-2 \\
11+>3-5\end{array}$ & $\begin{array}{l}0: 4,119,2.65,0.99 \\
1-2: 3,176,3.00,0.63 \\
3-5: 1,524,3.15,0.52 \\
6-10: 498,3.28,0.41 \\
11+: 86,3.29,0.42\end{array}$ \\
\hline New Transfers & 64.871 & $4,344.874$ & $<.01$ & .03 & $\begin{array}{l}1-2>0 \\
3-5>0 \\
3-5>1-2 \\
6-10>0 \\
6-10>1-2 \\
11+>0 \\
11+>1-2\end{array}$ & $\begin{array}{l}0: 3,469,2.64,1.04 \\
1-2: 1,559,2.86,0.70 \\
3-5: 690,3.00,0.61 \\
6-10: 219,3.10,0.52 \\
11+: 54,3.17,0.52\end{array}$ \\
\hline \multicolumn{7}{|c|}{ University Center for Academic Excellence } \\
\hline Aggregate & 71.482 & $4,3580.67$ & $<.01$ & .01 & $\begin{array}{l}3-5>0 \\
3-5>1-2 \\
6-20>0 \\
6-20>1-2 \\
6-20>3-5 \\
21+>0 \\
21+>1-2 \\
2+>3-5 \\
21+>6-20\end{array}$ & $\begin{array}{l}0: 5,170,2.77,0.98 \\
1-2: 4,289,2.77,0.82 \\
3-5: 2,731,2.89,0.71 \\
6-20: 2,640,2.96,0.63 \\
21+: 564,3.12,0.58\end{array}$ \\
\hline New Freshmen & 85.532 & $4,2608.894$ & $<.01$ & .03 & $\begin{array}{l}1-2>0 \\
3-5>0 \\
3-5>1-2 \\
6-20>0 \\
6-20>1-2 \\
6-20>3-5 \\
21+>0 \\
21+>1-2 \\
21+>3-5 \\
21+>6-20\end{array}$ & $\begin{array}{l}0: 1,985,2.72,0.91 \\
1-2: 2,803,2.80,0.82 \\
3-5: 2,117,2.95,0.69 \\
6-20: 1,970,3.04,0.61 \\
21+: 428,3.20,0.53\end{array}$ \\
\hline
\end{tabular}




\begin{tabular}{|c|c|c|c|c|c|c|}
\hline New Transfers & 5.869 & $4,839.437$ & $<.01$ & .003 & $\begin{array}{l}0>1-2 \\
0>3-5 \\
21+>1-2 \\
21+>3-5\end{array}$ & $\begin{array}{l}0: 3,185,2.80,1.02 \\
1-2: 1,386,2.69,0.82 \\
3-5: 614,2.70,0.73 \\
6-20: 670,2.75,0.66 \\
21+: 136,2.89,0.64\end{array}$ \\
\hline \multicolumn{7}{|c|}{ Writing Resources Center } \\
\hline Aggregate & 242.059 & $2,1379.898$ & $<.01$ & .02 & $\begin{array}{l}1>0 \\
2+>0 \\
2+>1\end{array}$ & $\begin{array}{l}0: 13,707,2.80,0.01 \\
1: 960,3.05,0.63 \\
2+: 727,3.21,0.52\end{array}$ \\
\hline New Freshmen & 203.62 & $2,963.90$ & $<.01$ & .02 & $\begin{array}{l}1>0 \\
2+>0 \\
2+>1\end{array}$ & \begin{tabular}{|l|}
$0: 8,222,2.85,0.79$ \\
$1: 704,3.06,0.63$ \\
$2+: 477,3.29,0.47$
\end{tabular} \\
\hline New Transfers & 53.929 & $2,409.377$ & $<.01$ & .008 & $\begin{array}{l}1>0 \\
2+>0\end{array}$ & \begin{tabular}{|l|}
$0: 5,485,2.74,0.93$ \\
$1: 256,3.02,0.61$ \\
$2+: 250,3.05,0.56$ \\
\end{tabular} \\
\hline \multicolumn{7}{|c|}{ University Speaking Center } \\
\hline Aggregate & 7.04 & $1,110.289$ & .009 & .0002 & $1+>0$ & $\begin{array}{l}0: 15,288,2.84,0.83 \\
1+: 106,2.95,0.45\end{array}$ \\
\hline New Freshmen & & & $\begin{array}{l}\text { Not } \\
\text { signif. }\end{array}$ & & & $\begin{array}{l}0: 9,318,2.88,0.77 \\
1+: 85,2.97,0.42\end{array}$ \\
\hline New Transfers & & & $\begin{array}{l}\text { Not } \\
\text { signif. }\end{array}$ & & & $\begin{array}{l}0: 5,970,2.76,0.91 \\
1+: 21,2.89,0.52\end{array}$ \\
\hline \multicolumn{7}{|c|}{ High-Impact Practices } \\
\hline Aggregate & 410.376 & $2,381.204$ & $<.01$ & .02 & $\begin{array}{l}1-2>0 \\
3-6>0 \\
3-6>1-2\end{array}$ & $\begin{array}{l}0: 14,881,2.82,0.83 \\
1-2: 269,3.23,0.50 \\
3-6: 244,3.50,0.39\end{array}$ \\
\hline New Freshmen & 247.224 & $2,227.67$ & $<.01$ & .025 & $\begin{array}{l}1-2>0 \\
3-6>0 \\
3-6>1-2\end{array}$ & $\begin{array}{l}0: 9,090,2.87,0.77 \\
1-2: 137,3.28,0.44 \\
3-6: 176,3.48,0.38\end{array}$ \\
\hline New Transfers & 160.82 & $2,131.991$ & $<.01$ & .01 & $\begin{array}{l}1-2>0 \\
3-6>0 \\
3-6>1-2\end{array}$ & $\begin{array}{l}0: 5,791,2.74,0.91 \\
1-2: 132,3.19,0.55 \\
3-6: 68,3.56,0.41 \\
\end{array}$ \\
\hline \multicolumn{7}{|c|}{ Greek Life Membership } \\
\hline Aggregate & 345.411 & $1,3044.881$ & $<.001$ & .01 & Yes $>$ No & $\begin{array}{l}\text { No: } 13,757,2.81,0.86 \\
\text { Yes: } 1,637,3.07,0.48\end{array}$ \\
\hline New Freshmen & 220.956 & 1, 3071.896 & $<.001$ & .01 & Yes $>$ No & $\begin{array}{l}\text { No: } 7,957,2.85,0.81 \\
\text { Yes: 1,428, 3.08, } 0.48\end{array}$ \\
\hline New Transfers & 42.284 & $1,268.43$ & $<.001$ & .002 & Yes $>$ No & $\begin{array}{l}\text { No: } 5,782,2.75,0.92 \\
\text { Yes: } 209,2.98,0.47\end{array}$ \\
\hline \multicolumn{7}{|c|}{ Sports Club Membership } \\
\hline Aggregate & 32.068 & $1,1030.188$ & $<.001$ & .001 & Yes $>$ No & $\begin{array}{l}\text { No: } 14,549,2.83,0.84 \\
\text { Yes: } 845,2.96,0.83\end{array}$ \\
\hline New Freshmen & 25.025 & $1,875.714$ & $<.001$ & .002 & Yes $>$ No & $\begin{array}{l}\text { No: } 8,715,2.88,0.78 \\
\text { Yes: } 688,3.00,0.61\end{array}$ \\
\hline
\end{tabular}




\begin{tabular}{|c|c|c|c|c|c|c|}
\hline New Transfers & & & $\begin{array}{l}\text { Not } \\
\text { signif. }\end{array}$ & & & \begin{tabular}{|l|} 
No: $5,834,2.76,0.92$ \\
Yes: $157,2.77,0.66$ \\
\end{tabular} \\
\hline \multicolumn{7}{|c|}{ Library Total Engagements } \\
\hline Aggregate & 151.417 & $4,6910.978$ & $<.001$ & .05 & $\begin{array}{l}3-9>0-2 \\
10-24>0-2 \\
10-24>3-9 \\
25-74>0-2 \\
25-74>3-9 \\
75+>0-2 \\
75+>3-9 \\
75+>10-24 \\
75+>25-74 \\
\end{array}$ & $\begin{array}{l}0-2: 3,854,2.53,1.23 \\
3-9: 3,407,2.83,0.78 \\
10-24: 3,150,2.96,0.67 \\
25-74: 3,355,2.98,0.60 \\
75+: 628,3.03,0.57\end{array}$ \\
\hline New Freshmen & 158.738 & $4,4204.027$ & $<.001$ & .09 & \begin{tabular}{|l}
$3-9>0-2$ \\
$10-24>0-2$ \\
$10-24>3-9$ \\
$25-74>0-2$ \\
$75+>0-2$ \\
$75+>3-9$ \\
$75+>10-24$ \\
$75+>25-74$
\end{tabular} & $\begin{array}{l}0-2: 1,892,2.44,1.06 \\
3-9: 2,173,2.87,0.73 \\
10-24: 2,065,3.02,0.63 \\
25-74: 2,234,3.05,0.56 \\
75+: 1,039,3.11,0.53\end{array}$ \\
\hline New Transfers & 18.54 & $4,2579.224$ & $<.001$ & .01 & $\begin{array}{l}3-9>0-2 \\
10-24>0-2 \\
25-74>0-2 \\
25-74>3-9 \\
75+>0-2 \\
75+>3-9 \\
\end{array}$ & $\begin{array}{l}0-2: 1,962,2.62,1.19 \\
\text { 3-9: } 1,234,2.76,0.85 \\
\text { 10-24: 1,085, 2.85, } 0.73 \\
25-74: 1,121,2.85,0.64 \\
75+: 589,2.89,0.59\end{array}$ \\
\hline \multicolumn{7}{|c|}{ Library Study Room Reservations } \\
\hline Aggregate & 334.92 & $3,4738.781$ & $<.01$ & .05 & $\begin{array}{l}1-5>0 \\
6-15>0 \\
6-15>15 \\
16+>0 \\
16+>1-5 \\
16+>6-15 \\
\end{array}$ & $\begin{array}{l}0: 8,807,2.68,0.94 \\
1-5: 3,429,2.98,0.61 \\
6-15: 1,641,3.06,0.58 \\
16+: 1,517,3.16,0.54\end{array}$ \\
\hline New Freshmen & 260.331 & $3,3360.855$ & $<.01$ & .07 & $\begin{array}{l}1-5>0 \\
6-15>0 \\
6-15>1-5 \\
16+>0 \\
16+>1-5 \\
16+>6-15\end{array}$ & $\begin{array}{l}0: 4,836,2.69,0.94 \\
1-5: 2,344,3.03,0.58 \\
6-15: 1,139,3.10,0.55 \\
16+: 1,084,3.20,0.52\end{array}$ \\
\hline New Transfers & 68,646 & $3,1339.642$ & $<.01$ & .023 & $\begin{array}{l}1-5>0 \\
6-15>0 \\
6-15>1-5 \\
16+>0 \\
16+>1-5 \\
\end{array}$ & $\begin{array}{l}0: 3,971,2.67,1.00 \\
1-5: 1,085,2.88,0.67 \\
6-15: 502,2.97,0.63 \\
16+: 433,3.07,0.59\end{array}$ \\
\hline
\end{tabular}




\begin{tabular}{|c|c|c|c|c|c|c|}
\hline \multicolumn{7}{|c|}{ Library Book Checkouts } \\
\hline Aggregate & 141.488 & $4,2630.137$ & $<.001$ & .03 & $\begin{array}{l}1>0 \\
2-3>0 \\
4-10>0 \\
4-10>1 \\
11+>0 \\
11+>2-3 \\
11+>4-10\end{array}$ & $\begin{array}{l}0: 11,047,2.76,0.88 \\
1: 1,160,2.97,0.66 \\
2-3: 1,125,3.00,0.67 \\
4-10: 1,276,3.16,0.62 \\
11+: 840,3.16,0.62\end{array}$ \\
\hline New Freshmen & 123.976 & $4,1797.084$ & $<.01$ & .04 & \begin{tabular}{|l}
$1>0$ \\
$2-3>0$ \\
$4-10>0$ \\
$4-10>1$ \\
$11+>0$ \\
$11+>2-3$ \\
$11+>4-10$
\end{tabular} & $\begin{array}{l}0: 6,443,2.79,0.81 \\
1: 760,3.00,0.63 \\
2-3: 780,3.09,0.63 \\
4-10: 877,3.11,0.60 \\
11+: 543,3.23,0.57\end{array}$ \\
\hline New Transfers & 24.472 & $4,826.188$ & $<.01$ & .01 & $\begin{array}{l}1>0 \\
2-3>0 \\
4-10>0 \\
11+>0 \\
11+>2-3\end{array}$ & $\begin{array}{l}0: 4,604,2.71,0.96 \\
1: 346,2.88,0.71 \\
2-3: 345,2.83,0.72 \\
4-10: 399,2.95,0.64 \\
11+: 297,3.03,0.68\end{array}$ \\
\hline \multicolumn{7}{|c|}{ Library Instruction } \\
\hline Aggregate & 204.046 & $3,5667.725$ & $<.01$ & .03 & $\begin{array}{l}1>0 \\
2>0 \\
2>1 \\
3+>1 \\
3+>2\end{array}$ & $\begin{array}{l}0: 6,737,2.69,0.95 \\
1: 4,856,2.89,0.74 \\
2: 2,162,2.97,0.66 \\
3+: 1,639,3.13,0.60\end{array}$ \\
\hline New Freshmen & 119.778 & $3,4326.086$ & $<.01$ & .03 & $\begin{array}{l}1>0 \\
2>0 \\
2>1 \\
3+>0 \\
3+>1 \\
3+>2\end{array}$ & $\begin{array}{l}0: 2,971,2.75,0.89 \\
1: 3,412,2,86,0.74 \\
2: 1,690,2.95,0.66 \\
3+: 1,330,3.16,0.59\end{array}$ \\
\hline New Transfers & 84.751 & $3,1065.538$ & $<.01$ & .033 & $\begin{array}{l}1>0 \\
2>0 \\
3+>0\end{array}$ & $\begin{array}{l}0: 3,776,2.63,0.99 \\
1: 1,444,2.95,0.75 \\
2: 472,3.03,0.63 \\
3+: 309,3.02,0.67\end{array}$ \\
\hline \multicolumn{7}{|c|}{ Library EZ Proxy } \\
\hline Aggregate & 225.047 & $5,785.886$ & $<.001$ & .05 & \begin{tabular}{|l|}
$1-5>0$ \\
$6-10>0$ \\
$6-10>1-5$ \\
$11-20>0$ \\
$11-20>1-5$ \\
$21-30>0$ \\
$21-30>1-5$ \\
$31+>0$ \\
$31+>1-5$ \\
$31>6-10$ \\
$31+>21-30$
\end{tabular} & $\begin{array}{l}0: 9,751,2.69,0.92 \\
1-5: 1,757,3.03,0.55 \\
6-10: 629,3.13,0.53 \\
11-20: 474,3.21,0.54 \\
21-30: 172,3.21,0.60 \\
31+: 164,3.44,0.52\end{array}$ \\
\hline
\end{tabular}




\begin{tabular}{|c|c|c|c|c|c|c|}
\hline New Freshmen & 165.831 & $5,591.089$ & $<.001$ & .06 & $\begin{array}{l}1-5>0 \\
6-10>0 \\
6-10>1-5 \\
11-20>0 \\
11-20>1-5 \\
21-30>0 \\
21-30>1-5 \\
21-30>6-10 \\
31+>0 \\
31+>1-5 \\
31+>6-10 \\
31+>11-20 \\
\end{array}$ & $\begin{array}{l}0: 5,395,2.71,0.87 \\
1-5: 1,359,3.04,0.53 \\
6-10: 504,3.15,0.51 \\
11-20: 378,3.20,0.53 \\
21-30: 137,3.31,0.46 \\
31+: 108,3.42,0.45\end{array}$ \\
\hline New Transfers & 52.883 & $5,175.591$ & $<.001$ & .03 & $\begin{array}{l}1-5>0 \\
6-10>0 \\
11-20>0 \\
11-20>1-5 \\
31+>0 \\
31+>1-5 \\
31+>6-10 \\
31+>21-30 \\
\end{array}$ & $\begin{array}{l}0: 4,356,2.66,0.98 \\
1-5: 398,2.98,0.61 \\
6-10: 125,3.05,0.58 \\
11-20: 96,3.26,0.57 \\
21-30: 35,2.84,0.87 \\
31+: 56,3.48,0.65\end{array}$ \\
\hline \multicolumn{7}{|c|}{ Library After-Hours Visits } \\
\hline Aggregate & 36.942 & $3,1010.387$ & $<.001$ & .004 & $\begin{array}{l}1>0 \\
2-5>0 \\
6+>0 \\
6+>1 \\
6+>2-5 \\
\end{array}$ & $\begin{array}{l}0: 13,427,282,0.86 \\
1: 871,2.94,0.54 \\
2-5: 796,2.94,0.55 \\
6+: 300,3.05,0.52\end{array}$ \\
\hline New Freshmen & 23.155 & $3,768.79$ & $<.001$ & .004 & $\begin{array}{l}1>0 \\
2-5>0 \\
6+>0 \\
6+>2-5\end{array}$ & $\begin{array}{l}0: 7,930,2.86,0.81 \\
1: 645,2.98,0.64 \\
2-5: 604,2.97,0.52 \\
6+: 224,3.08,0.50\end{array}$ \\
\hline New Transfers & 6.249 & $3,241.685$ & $<.001$ & .05 & $6+>0$ & $\begin{array}{l}0: 5,497,2.75,0.93 \\
1: 226,2.83,0.54 \\
2-5: 192,2.85,0.63 \\
6+: 76,2.97,0.55\end{array}$ \\
\hline \multicolumn{7}{|c|}{ Library Computer Logins } \\
\hline Aggregate & 81.265 & $3,7158.776$ & $<.01$ & .02 & $\begin{array}{l}1-10>0 \\
11-30>0 \\
11-30>1-10 \\
31+>0 \\
31+>1-10\end{array}$ & $\begin{array}{l}0: 3,684,2.64,1.12 \\
1-10: 6,380,2.86,0.77 \\
11-30: 2,958,2.94,0.62 \\
31+: 2,362,2.96,0.59\end{array}$ \\
\hline New Freshmen & 104.342 & $3,4151.492$ & $<.01$ & .04 & $\begin{array}{l}1-10>0 \\
11-30>0 \\
11-30>1-10 \\
31+>0 \\
31+>1-10\end{array}$ & $\begin{array}{l}0: 1,916,2.58,1.03 \\
1-10: 4,172,2.92,0.73 \\
11-30: 1,903,3.00,0.58 \\
31+: 1,412,3.05,0.55\end{array}$ \\
\hline
\end{tabular}




\begin{tabular}{|c|c|c|c|c|c|c|}
\hline New Transfers & 5.701 & $3,2,927.041$ & $<.01$ & .003 & $\begin{array}{l}11-30>0 \\
31+>0\end{array}$ & $\begin{array}{l}0: 1,778,2.70,1.20 \\
1-10: 2,208,2.76,0.84 \\
11-30: 1,055,2.82,0.68 \\
31+: 950,2.82,0.62\end{array}$ \\
\hline \multicolumn{7}{|c|}{ Library Laptop Checkouts } \\
\hline Aggregate & 41.376 & $3,2943.09$ & $<.001$ & .01 & $\begin{array}{l}1>0 \\
2-10>0 \\
11+>0\end{array}$ & $\begin{array}{l}0: 11,166,2.80,0.90 \\
1: 1,126,2.95,0.64 \\
2-10: 1,970,2.94,0.62 \\
11+: 1,132,2.92,0.56\end{array}$ \\
\hline New Freshmen & 38.089 & $3,2123.264$ & $<.001$ & .01 & $\begin{array}{l}1>0 \\
2-10>0 \\
11+>0\end{array}$ & $\begin{array}{l}0: 4,781,2.75,0.97 \\
1: 317,2.85,0.69 \\
2-10: 1,428,3.00,0.59 \\
11+: 351,2.76,0.55\end{array}$ \\
\hline New Transfers & & & $\begin{array}{l}\text { Not } \\
\text { signif. }\end{array}$ & & & $\begin{array}{l}0: 4,781,2.75,0.97 \\
1: 317,2.85,0.69 \\
2-10: 542,2.80,0.66 \\
11+: 351,2.76,0.55\end{array}$ \\
\hline \multicolumn{7}{|c|}{ Library Other Checkouts } \\
\hline Aggregate & 46.661 & $4,2325.356$ & $<.001$ & .01 & $\begin{array}{l}1>0 \\
2-3>0 \\
4-10>0 \\
11+>0\end{array}$ & $\begin{array}{l}0: 11,486,2.79,0.88 \\
1: 1,259,2.97,0.64 \\
2-3: 912,2.99,0.64 \\
4-10: 889,2.98,0.65 \\
11+: 848,2.93,0.61\end{array}$ \\
\hline New Freshmen & 39.903 & $4,1617.66$ & $<.001$ & .01 & $\begin{array}{l}1>0 \\
2-3>0 \\
4-10>0 \\
11+>0\end{array}$ & $\begin{array}{l}0: 6,713,2.83,0.82 \\
1: 865,3.01,0.61 \\
2-3: 623,3.04,0.63 \\
4-10: 634,3.04,0.61 \\
11+: 568,3.00,0.59\end{array}$ \\
\hline New Transfers & 6.530 & $4,701.275$ & $<.001$ & .003 & $\begin{array}{l}1>0 \\
2-3>0\end{array}$ & $\begin{array}{l}0: 4,773,2.74,0.96 \\
1: 394,2.88,0.69 \\
2-3: 289,2.88,0.65 \\
4-10: 255,2.85,0.73 \\
11+: 280,2.78,0.63\end{array}$ \\
\hline
\end{tabular}




\begin{tabular}{|c|c|c|c|c|c|c|}
\hline \multicolumn{7}{|c|}{$\begin{array}{c}\text { TABLE A.2 } \\
\text { Credits Earned/Attempted: ANOVAs \& Descriptives }\end{array}$} \\
\hline $\begin{array}{l}\text { Independent } \\
\text { Variables }\end{array}$ & $\mathbf{F}$ & df & Sig. $(p)$ & $\begin{array}{l}\text { Effect } \\
\left(\mathbf{n}_{p}^{2}\right)\end{array}$ & $\begin{array}{l}\text { Post Hoc } \\
\text { Sig. Results* }\end{array}$ & $\begin{array}{l}\text { Descriptives } \\
\text { (Group: N, Mean, SD) }\end{array}$ \\
\hline \multicolumn{7}{|c|}{ Total Engagements Overall } \\
\hline Aggregate & 103.323 & $5,4036.062$ & $<.001$ & .05 & $\begin{array}{l}1-9>0 \\
10-24>0 \\
10-24>1-9 \\
25-49>0 \\
25-49>1-9 \\
25-49> \\
10-24 \\
50-74>0 \\
50-74>1-9 \\
50-74> \\
10-24 \\
75+>0 \\
75+>1-9 \\
75+>10-24\end{array}$ & $\begin{array}{l}0: 671,0.710,0.36 \\
1-9: 4,137,0.808,0.25 \\
10-24: 3,602,0.872,0.18 \\
25-49: 2,866,0.885,0.15 \\
50-74: 1,258,0.890,0.14 \\
75+: 1,996,0.897,0.13\end{array}$ \\
\hline New Freshmen & 83.251 & $5,1259.040$ & $<.001$ & .07 & $\begin{array}{l}1-9>0 \\
10-24>0 \\
10-24>1-9 \\
25-49>0 \\
25-49>1-9 \\
25-49> \\
10-24 \\
50-74>0 \\
50-74>1-9 \\
50-74> \\
10-24 \\
75+>0 \\
75+>1-9 \\
75+>10-24 \\
75+>25-49 \\
\end{array}$ & $\begin{array}{l}0: 141,0.647,0.36 \\
\text { 1-9: } 2,252,0.801,0.25 \\
\text { 10-24: } 2,402,0.880,0.17 \\
25-49: 1,958,0.898,0.13 \\
50-74: 855,0.902,0.12 \\
75+: 1,315,0.911,0.11\end{array}$ \\
\hline New Transfers & 22.282 & $5,1891.316$ & $<.001$ & .03 & \begin{tabular}{|l}
$1-9>0$ \\
$10-24>0$ \\
$10-24>1-9$ \\
$25-49>0$ \\
$25-49>1-9$ \\
$50-74>0$ \\
$50-74>1-9$ \\
$75+>0$ \\
$75+>1-9$
\end{tabular} & $\begin{array}{l}0: 530,0.727,0.36 \\
\text { 1-9: 1,855, 0.816, } 0.26 \\
\text { 10-24: 1,200, 0.856, } 0.20 \\
25-49: 908,0.858,0.18 \\
50-74: 403,0.867,0.16 \\
75+: 681,0.868,0.15\end{array}$ \\
\hline
\end{tabular}




\begin{tabular}{|c|c|c|c|c|c|c|}
\hline \multicolumn{7}{|c|}{ University Career Center } \\
\hline Aggregate & 254.955 & $4,985.036$ & $<.001$ & .05 & $\begin{array}{l}1-2>0 \\
3-5>0 \\
3-5>1-2 \\
6-10>0 \\
6-10>1-2 \\
6-10>3-5 \\
11+>0 \\
11+>1-2\end{array}$ & $\begin{array}{l}0: 6,840,0.807,0.25 \\
1-2: 4,632,0.881,0.17 \\
3-5: 2,202,0.911,0.13 \\
6-10: 716,0.937,0.09 \\
11+: 140,0.927,0.09\end{array}$ \\
\hline New Freshmen & 204.711 & $4,634.782$ & $<.001$ & .07 & $\begin{array}{l}1-2>0 \\
3-5>0 \\
3-5>1-2 \\
6-10>0 \\
6-10>1-2 \\
6-10>3-5 \\
11+>0 \\
11+>1-2 \\
11+>3-5\end{array}$ & $\begin{array}{l}0: 3,704,0.813,0.23 \\
1-2: 3,115,0.890,0.152 \\
3-5: 1,520,0.921,0.114 \\
6-10: 498,0.947,0.074 \\
11+: 86,0.942,0.064\end{array}$ \\
\hline New Transfers & 56.772 & $4,351.938$ & $<.001$ & .03 & $\begin{array}{l}1-2>0 \\
3-5>0 \\
3-5>1-2 \\
6-10>0 \\
6-10>1-2 \\
11+>0\end{array}$ & $\begin{array}{l}0: 3,136,0.800,0.264 \\
1-2: 1,517,0.861,0.19 \\
3-5: 682,0.888,0.14 \\
6-10: 218,0.913,0.12 \\
11+: 54,0.903,0.12\end{array}$ \\
\hline \multicolumn{7}{|c|}{ University Center for Academic Excellence } \\
\hline Aggregate & 42.563 & $4,3601.811$ & $<.001$ & .01 & $\begin{array}{l}3-5>0 \\
3-5>1-2 \\
6-20>0 \\
6-20>1-2 \\
6-20>3-5 \\
21+>0 \\
21+>1-2 \\
21+>3-5\end{array}$ & $\begin{array}{l}0: 4,765,0.834,0.242 \\
1-2: 3,995,0.845,0.21 \\
3-5: 2,626,0.868,0.18 \\
6-20: 2,593,0.881,0.15 \\
21+: 561,0.897,0.13\end{array}$ \\
\hline New Freshmen & 47.456 & $4,2654.014$ & $<.001$ & .02 & $\begin{array}{l}1-2>0 \\
3-5>0 \\
3-5>1-2 \\
6-20>0 \\
6-20>1-2 \\
6-20>3-5 \\
21+>0 \\
21+>1-2 \\
21+>3-5 \\
21+>6-20 \\
\end{array}$ & $\begin{array}{l}0: 1,833,0.830,0.28 \\
1-2: 2,693,0.855,0.2 \\
3-5: 2,034,0.879,0.17 \\
6-20: 1,938,0.895,0.14 \\
21+: 425,0.913,0.11\end{array}$ \\
\hline New Transfers & & & $\begin{array}{l}\text { Not } \\
\text { signif. }\end{array}$ & .001 & & $\begin{array}{l}0: 2,932,0.837,0.25 \\
1-2: 1,302,0.823,0.22 \\
3-5: 582,0.827,0.21 \\
6-20: 655,0.836,0.18 \\
21+: 136,0.848,0.17\end{array}$ \\
\hline
\end{tabular}




\begin{tabular}{|c|c|c|c|c|c|c|}
\hline \multicolumn{7}{|c|}{ Writing Resources Center } \\
\hline Aggregate & 214.772 & $2,1492.422$ & $<.001$ & .01 & $\begin{array}{l}1>0 \\
2+>0 \\
2+>1\end{array}$ & $\begin{array}{l}0: 12,869,0.846,0.21 \\
1: 938,0.899,0.15 \\
2+: 723,0.928,0.10\end{array}$ \\
\hline New Freshmen & 156.388 & $2,1052.834$ & $<.001$ & .01 & $\begin{array}{l}1>0 \\
2+>0 \\
2+>1\end{array}$ & $\begin{array}{l}0: 7,765,0.896,0.00 \\
1: 684,0.093,0.144 \\
2+: 474,0.940,0.09 \\
\end{array}$ \\
\hline New Transfers & 61.166 & $2,34.730$ & $<.001$ & .01 & $\begin{array}{l}1>0 \\
2+>0\end{array}$ & $\begin{array}{l}0: 5,104,0.827,0.24 \\
1: 254,0.894,0.15 \\
2+: 249,0.907,0.12 \\
\end{array}$ \\
\hline \multicolumn{7}{|c|}{ University Speaking Center } \\
\hline Aggregate & 60.125 & $1,14528.00$ & $<.001$ & .001 & $1+>0$ & $\begin{array}{l}0: 14,423,0.853,0.01 \\
1+: 107,0.916,0.08\end{array}$ \\
\hline New Freshmen & 45.928 & $1,95.546$ & $<.001$ & .001 & $1+>0$ & $\begin{array}{l}0: 8,838,0.867,0.19 \\
1+: 85,0.921,0.07\end{array}$ \\
\hline New Transfers & & & $\begin{array}{l}\text { Not } \\
\text { signif. }\end{array}$ & & & $\begin{array}{l}0: 5,585,0.833,0.23 \\
1+: 22,0.895,0.11 \\
\end{array}$ \\
\hline \multicolumn{7}{|c|}{ High-Impact Practices } \\
\hline Aggregate & 339.795 & $2,416.382$ & $<.001$ & .01 & $\begin{array}{l}1-2>0 \\
3-6>0 \\
3-6>1-2\end{array}$ & $\begin{array}{l}0: 14,017,0.850,0.21 \\
1-2: 268,0.935,0.10 \\
3-6: 246,0.965,0.07\end{array}$ \\
\hline New Freshmen & 277.712 & $2,256.939$ & $<.001$ & .01 & $\begin{array}{l}1-2>0 \\
3-6>0 \\
3-6>1-2\end{array}$ & $\begin{array}{l}0: 8,610,0.863,0.19 \\
1-2: 137,0.946,0.08 \\
3-6: 176,0.969,0.06\end{array}$ \\
\hline New Transfers & 89.201 & $2,138.205$ & $<.001$ & .01 & $\begin{array}{l}1-2>0 \\
3-6>0\end{array}$ & $\begin{array}{l}0: 5,407,0.829,0.23 \\
1-2: 131,0.924,0.11 \\
3-6: 69,0.956,0.10\end{array}$ \\
\hline \multicolumn{7}{|c|}{ Greek Life Membership } \\
\hline Aggregate & 451.038 & $1,3730.931$ & $<.001$ & .01 & Yes $>$ No & $\begin{array}{l}\text { No: } 12,901,0.846,0.21 \\
\text { Yes: } 1,629,0.914,0.10\end{array}$ \\
\hline New Freshmen & 289.644 & $1,4001.855$ & $<.001$ & .01 & Yes $>$ No & $\begin{array}{l}\text { No: } 7,501,0.858,0.20 \\
\text { Yes: } 1,422,0.917,0.10\end{array}$ \\
\hline New Transfers & 43.698 & $1,258.653$ & $<.001$ & .003 & Yes $>$ No & $\begin{array}{l}\text { No: } 5,400,0.831,0.23 \\
\text { Yes: } 207,0.895,0.13\end{array}$ \\
\hline \multicolumn{7}{|c|}{ Sports Club Membership } \\
\hline Aggregate & 30.517 & $1,1054.181$ & $<.001$ & .01 & Yes $>$ No & $\begin{array}{l}\text { No: } 12,901,0.846,0.21 \\
\text { Yes: } 1,629,0.914,0.10\end{array}$ \\
\hline New Freshmen & 22.162 & $1,908.624$ & $<.001$ & .003 & Yes $>$ No & $\begin{array}{l}\text { No: } 7,501,0.858,0.20 \\
\text { Yes: } 1,422,0.917,0.10\end{array}$ \\
\hline New Transfers & & & $\begin{array}{l}\text { Not } \\
\text { signif. }\end{array}$ & & & $\begin{array}{l}\text { No: } 5,400,0.831,0.23 \\
\text { Yes: } 207,0.895,0.13\end{array}$ \\
\hline
\end{tabular}




\begin{tabular}{|c|c|c|c|c|c|c|}
\hline \multicolumn{7}{|c|}{ Library Total Engagements } \\
\hline Aggregate & 114.184 & $4,6672.966$ & $<.001$ & .04 & $\begin{array}{l}3-9>0-2 \\
10-24>0-2 \\
10-24>3-9 \\
25-74>0-2 \\
25-74>3-9 \\
75+>0-1 \\
75+>3-9\end{array}$ & $\begin{array}{l}0-2: 3,262,0.778,0.291 \\
3-9: 3,229,0.8502,0.203 \\
10-24: 3,080,0.882,0.165 \\
25-74: 3,337,0.886,0.147 \\
75+: 1,622,0.893,0.13\end{array}$ \\
\hline New Freshmen & 92.327 & $4,3982.122$ & $<.001$ & .06 & $\begin{array}{l}3-9>0-2 \\
10-24>0-2 \\
10-24>3-9 \\
25-74>0-2 \\
25-74>3-9 \\
75+>0-1 \\
75+>3-9\end{array}$ & $\begin{array}{l}0-2: 1,553,0.771,0.282 \\
3-9: 2,073,0.857,0.193 \\
10-24: 2,035,0.896,0.144 \\
25-74: 2,224,0.899,0.132 \\
75+: 1,038,0.867,0.116\end{array}$ \\
\hline New Transfers & 23.705 & $4,2503.512$ & $<.001$ & .02 & $\begin{array}{l}3-9>0-2 \\
10-24>0-2 \\
25-74>0-2 \\
75+>0-1 \\
75+>3-9\end{array}$ & $\begin{array}{l}0-2: 1,709,0.785,0.300 \\
3-9: 1,156,0.838,0.219 \\
10-24: 1,045,0.856,0.197 \\
25-74: 1,113,0.86,0.171 \\
75+: 584,0.8682,0.148\end{array}$ \\
\hline \multicolumn{7}{|c|}{ Library Study Room Reservations } \\
\hline Aggregate & 205.439 & $3,4917.736$ & $<.001$ & .03 & $\begin{array}{l}1-5>0 \\
6-15>0 \\
6-15>1-5 \\
16+>0 \\
16+>1-5\end{array}$ & $\begin{array}{l}0: 8,027,0.820,0.24 \\
1-5: 3,364,0.887,0.15 \\
6-15: 1,628,0.901,0.13 \\
16+: 1,511,0.909,0.12\end{array}$ \\
\hline New Freshmen & 137.927 & $3,3471.839$ & $<.001$ & .04 & $\begin{array}{l}1-5>0 \\
6-10>0 \\
16+>0 \\
16+>1-5 \\
\end{array}$ & $\begin{array}{l}0: 4,402,0.828,0.23 \\
1-5: 2,310,0.898,0.14 \\
6-15: 1,131,0.908,0.12 \\
16+: 1,080,0.916,0.12\end{array}$ \\
\hline New Transfers & 52.470 & $3,1378.605$ & $<.001$ & .02 & $\begin{array}{l}1-5>0 \\
6-15>0 \\
16+>0 \\
16+>1-5\end{array}$ & $\begin{array}{l}0: 3,625,0.810,0.26 \\
1-5: 1,054,0.863,0.18 \\
6-15: 497,0.847,0.15 \\
16+: 431,0.892,0.14\end{array}$ \\
\hline \multicolumn{7}{|c|}{ Library Book Checkouts } \\
\hline Aggregate & 84.39 & $4,2728.545$ & $<.001$ & .02 & \begin{tabular}{|l}
$1>0$ \\
$2-3>0$ \\
$4-10>0$ \\
$4-10>1$ \\
$11+>0$ \\
$11+>1$ \\
$11+>2-3$ \\
\end{tabular} & $\begin{array}{l}0: 10,185,0.837,0.225 \\
1: 1,106,0.883,0.156 \\
2-3: 1,125,0.885,0.159 \\
4-10: 1,275,0.898,0.140 \\
11+: 839,0.908,0.137\end{array}$ \\
\hline
\end{tabular}




\begin{tabular}{|c|c|c|c|c|c|c|}
\hline New Freshmen & 74.835 & $4,1903.512$ & $<.001$ & .02 & $\begin{array}{l}1>0 \\
2-3>0 \\
4-10>0 \\
4-10>1 \\
11+>0 \\
11+>1 \\
11+>2-3\end{array}$ & $\begin{array}{l}0: 5,964,0.8481,0.208 \\
1: 760,0.891,0.141 \\
2-3: 780,0.900,0.144 \\
4-10: 876,0.911,0.123 \\
11+: 543,0.924,0.112\end{array}$ \\
\hline New Transfers & 13.943 & $4,834.396$ & $<.001$ & .01 & $\begin{array}{l}1>0 \\
2-3>0 \\
4-10>0 \\
11+>0\end{array}$ & $\begin{array}{l}0: 4,221,0.822,0.246 \\
1: 346,0.865,0.184 \\
2-3: 345,0.853,0.185 \\
4-10: 399,0.869,0.168 \\
11+: 296,0.877,0.169\end{array}$ \\
\hline \multicolumn{7}{|c|}{ Library Instruction } \\
\hline Aggregate & 132.657 & $3,5698.625$ & $<.001$ & .02 & $\begin{array}{l}1>0 \\
2>0 \\
2>1 \\
3+>0 \\
3+>1 \\
3+>2\end{array}$ & $\begin{array}{l}0: 6,186,0.821,0.242 \\
1: 4,616,0.866,0.184 \\
2: 2,101,0.882,0.166 \\
3+: 1,627,0.910,0.137\end{array}$ \\
\hline New Freshmen & 69.740 & $3,4285.933$ & $<.001$ & .02 & $\begin{array}{l}1>0 \\
2>0 \\
2>1 \\
3+>0 \\
3+>1 \\
3+>2\end{array}$ & $\begin{array}{l}0: 2,744,0.841,0.221 \\
1: 3,222,0.863,0.183 \\
2: 1,636,0.879,0.169 \\
3+: 1,321,0.916,0.129\end{array}$ \\
\hline New Transfers & 58.089 & $3,1073.761$ & $<.001$ & .02 & $\begin{array}{l}1>0 \\
2>0 \\
2>1 \\
3+>0 \\
3+>1 \\
3+>2\end{array}$ & $\begin{array}{l}0: 3,442,0.805,0.257 \\
1: 1,394,0.872,0.185 \\
2: 465,0.893,0.153 \\
3+: 306,0.883,0.166\end{array}$ \\
\hline \multicolumn{7}{|c|}{ Library EZ Proxy } \\
\hline Aggregate & 127.215 & $5,817.761$ & $<.001$ & .03 & $\begin{array}{l}1-5>0 \\
6-10>0 \\
6-10>1-5 \\
11-20>0 \\
11-20>1-5 \\
21-30>0 \\
21-30>1-5 \\
21-30>6-10 \\
31+>0 \\
31+>1-5 \\
31+>6-10\end{array}$ & $\begin{array}{l}0: 8,907,0.822,0.238 \\
1-5: 1,754,0.885,0.138 \\
6-10: 628,0.902,0.114 \\
11-20: 474,0.918,0.109 \\
21-30: 171,0.929,0.092 \\
31+: 163,0.933,0.114\end{array}$ \\
\hline
\end{tabular}




\begin{tabular}{|c|c|c|c|c|c|c|}
\hline New Freshmen & 115.664 & $5,632.374$ & $<.001$ & .04 & $\begin{array}{l}1-5>0 \\
6-10>0 \\
6-10>1-5 \\
11-20>0 \\
11-20>1-5 \\
21-30>0 \\
21-30>1-5 \\
21-30>6-10 \\
31+>0 \\
31+>1-5 \\
31+>6-10\end{array}$ & $\begin{array}{l}0: 4,922,0.830,0.223 \\
1-5: 1,357,0.892,0.130 \\
6-10: 503,0.912,0.104 \\
11-20: 378,0.930,0.086 \\
21-30: 137,0.945,0.074 \\
31+: 108,0.942,0.080\end{array}$ \\
\hline New Transfers & 12.823 & $5,179.36$ & $<.001$ & .01 & $\begin{array}{l}1-5>0 \\
6-10>0 \\
11-20>0 \\
31+>0\end{array}$ & $\begin{array}{l}0: 3,985,0.813,0.255 \\
1-5: 397,0.862,0.160 \\
6-10: 125,0.864,0.141 \\
11-20: 96,0.872,0.167 \\
21-30: 34,0.866,0.126 \\
31+: 55,0.916,0.161\end{array}$ \\
\hline \multicolumn{7}{|c|}{ Library After-Hours Visits } \\
\hline Aggregate & 40.231 & $3,1047.158$ & $<.001$ & .004 & $\begin{array}{l}1>0 \\
2-5>0 \\
6+>0\end{array}$ & $\begin{array}{l}0: 12,563,0.849,0.217 \\
1: 871,0.885,0.122 \\
2-5: 796,0.884,0.123 \\
6+: 300,0.891,0.115\end{array}$ \\
\hline New Freshmen & 23.832 & $3,798.612$ & $<.001$ & .004 & $\begin{array}{l}1>0 \\
2-5>0 \\
6+>0\end{array}$ & $\begin{array}{l}0: 7,450,0.862,0.199 \\
1: 645,0.892,0.116 \\
2-5: 604,0.893,0.113 \\
6+: 224,0.899,0.111\end{array}$ \\
\hline New Transfers & 6.990 & $3,347.375$ & $<.001$ & .002 & $\begin{array}{l}1>0 \\
2-5>0\end{array}$ & $\begin{array}{l}0: 5,113,0.830,0.239 \\
1: 226,0.864,0.135 \\
2-5: 192,0.858,0.147 \\
6+: 76,0.865,0.122\end{array}$ \\
\hline \multicolumn{7}{|c|}{ Library Computer Logins } \\
\hline Aggregate & 74.533 & $3,6800.293$ & $<.001$ & .02 & $\begin{array}{l}1-10>0 \\
11-30>0 \\
11-30>1-10 \\
31+>0 \\
31+>1-10\end{array}$ & $\begin{array}{l}0: 3,201,0.8007,0.280 \\
1-10: 6,069,0.860,0.200 \\
11-30: 2,912,0.877,0.160 \\
31+: 2,348,0.882,0.144\end{array}$ \\
\hline New Freshmen & 69.830 & $3,3955.609$ & $<.001$ & .03 & $\begin{array}{l}1-10>0 \\
11-30>0 \\
11-30>1-10 \\
31+>0 \\
31+>1-10 \\
\end{array}$ & $\begin{array}{l}0: 1,645,0.8006,0.267 \\
1-10: 3,986,0.871,0.181 \\
11-30: 1,883,0.891,0.140 \\
31+: 1,409,0.901,0.120\end{array}$ \\
\hline New Transfers & 12.849 & $3,2756.956$ & $<.001$ & .01 & $\begin{array}{l}1-10>0 \\
11-30>0 \\
31+>0\end{array}$ & $\begin{array}{l}0: 1,556,0.8008,0.294 \\
1-10: 2,083,0.838,0.220 \\
11-30: 1,029,0.851,0.189 \\
31+: 939,0.855,0.170\end{array}$ \\
\hline
\end{tabular}




\begin{tabular}{|c|c|c|c|c|c|c|}
\hline \multicolumn{7}{|c|}{ Library Laptop Checkouts } \\
\hline Aggregate & 42.771 & $3,3010.887$ & $<.001$ & .01 & $\begin{array}{l}1>0 \\
2-10>0 \\
11+>0\end{array}$ & $\begin{array}{l}0: 10,302,0.844,0.225 \\
1: 1,126,0.876,0.161 \\
2-10: 1,970,0.880,0.132 \\
11+: 1,132,0.881,0.132 \\
\end{array}$ \\
\hline New Freshmen & 36.587 & $3,2172.378$ & $<.001$ & .01 & $\begin{array}{l}1>0 \\
2-10>0 \\
11+>0\end{array}$ & $\begin{array}{l}0: 5,905,0.854,0.208 \\
1: 809,0.885,0.151 \\
2-10: 1,428,0.895,0.135 \\
11+: 781,0.893,0.129\end{array}$ \\
\hline New Transfers & 4.034 & $3,822.507$ & .007 & .001 & $11+>0$ & $\begin{array}{l}0: 4,397,0.829,0.25 \\
1: 317,0.852,0.18 \\
2-10: 542,0.841,0.186 \\
11+: 351,0.853,0.134\end{array}$ \\
\hline \multicolumn{7}{|c|}{ Library Other Checkouts } \\
\hline Aggregate & 36.523 & $4,2374.649$ & $<.001$ & .01 & $\begin{array}{l}1>0 \\
2-3>0 \\
4-10>0 \\
11+>0\end{array}$ & $\begin{array}{l}0: 10,623,0.843,0.22 \\
1: 1,259,0.88,0.16 \\
2-3: 912,0.886,0.16 \\
4-10: 888,0.883,0.16 \\
11+: 848,0.878,0.143\end{array}$ \\
\hline New Freshmen & 28.340 & $4,1657.519$ & $<.001$ & .01 & $\begin{array}{l}1<0 \\
2-3<0 \\
4-10<0 \\
11+<0\end{array}$ & $\begin{array}{l}0: 6,233,0.855,0.20 \\
1: 865,0.893,0.14 \\
2-3: 623,0.902,0.14 \\
4-10: 634,0.896,0.14 \\
11+: 568,0.888,0.14 \\
\end{array}$ \\
\hline New Transfers & 6.074 & $4,709.555$ & $<.001$ & .003 & $\begin{array}{l}1>0 \\
11+>0\end{array}$ & $\begin{array}{l}0: 4,390,0.826,0.25 \\
1: 394,0.861,0.18 \\
2-3: 289,0.854,0.18 \\
4-10: 254,0.851,0.18 \\
11+: 280,0.856,0.144\end{array}$ \\
\hline \multicolumn{7}{|c|}{ Library Special Collections } \\
\hline Aggregate & 12.795 & $1,69.288$ & .001 & .0002 & $1+>0$ & $\begin{array}{l}0: 14,462,0.854,0.21 \\
1+: 68,0.901,0.11 \\
\end{array}$ \\
\hline New Freshmen & 17.677 & $1,53.781$ & $<.001$ & .0004 & $1+>0$ & $\begin{array}{l}0: 14,462,0.854,0.21 \\
1+: 68,0.901,0.11 \\
\end{array}$ \\
\hline New Transfers & & & $\begin{array}{l}\text { Not } \\
\text { signif. }\end{array}$ & & & $\begin{array}{l}0: 5,591,0.833,0.23 \\
1+: 16,0.845,0.15\end{array}$ \\
\hline
\end{tabular}

*Significance threshold at $p<.05$. Welch's ANOVA test used due to prevalence of unequal sample sizes. Games-Howell Post Hoc Analysis used, which aligns with Welch's ANOVAs. 


\section{APPENDIX B. Regression Models}

\begin{tabular}{|c|c|c|c|}
\hline \multicolumn{4}{|c|}{$\begin{array}{l}\text { TABLE B.1 } \\
\text { Four-Year Cumulative GPA Significant Regression Models }\end{array}$} \\
\hline Independent Variable & Aggregate (B) & $\begin{array}{l}\text { Entered as } \\
\text { Freshman }(B)\end{array}$ & $\begin{array}{l}\text { Entered as } \\
\text { Transfer }(B)\end{array}$ \\
\hline \multicolumn{4}{|l|}{ Total Engagements x Partner } \\
\hline $\begin{array}{l}\text { Constant } \\
\text { Career Center } \\
\text { Library } \\
\text { Univ Ctr for Acad Excel. } \\
\text { Writing Center } \\
\text { Speaking Center } \\
\text { High-Impact Practices } \\
\text { Greek Life Membership } \\
\text { Sports Clubs Membership }\end{array}$ & $\begin{array}{l}2.678 \\
.059 \\
.001 \\
.004 \\
.025 \\
- \\
.169 \\
.184 \\
- \\
\end{array}$ & $\begin{array}{l}2.684 \\
.061 \\
.001 \\
.006 \\
.028 \\
- \\
.144 \\
.161 \\
-\end{array}$ & $\begin{array}{l}2.669 \\
.056 \\
- \\
- \\
.021 \\
- \\
.228 \\
.152 \\
- \\
\end{array}$ \\
\hline & $\begin{array}{l}R^{2}=.063 \\
F_{(6,15387)}=173.66 \\
p<.001\end{array}$ & $\begin{array}{l}R^{2}=.087 \\
F_{(6,9396)}=149.404 \\
p<.001\end{array}$ & $\begin{array}{l}R^{2}=.035 \\
F_{(4,5986)}=53.818 \\
p<.001\end{array}$ \\
\hline \multicolumn{4}{|c|}{ Precollege/Demographic Variables \& All Activities } \\
\hline Constant & .763 & .626 & 1.031 \\
\hline \multicolumn{4}{|l|}{ Precollege/Demographics } \\
\hline $\begin{array}{l}\text { HS GPA } \\
\text { ACT/SAT Standardized } \\
\text { Pell: Total Awarded } \\
\text { Non UNCC Credits }\end{array}$ & $\begin{array}{l}.475 \\
- \\
-003\end{array}$ & $\begin{array}{l}.514 \\
- \\
-002\end{array}$ & $\begin{array}{l}.368 \\
- \\
-005\end{array}$ \\
\hline \multicolumn{4}{|l|}{ Student Affairs } \\
\hline $\begin{array}{l}\text { High-Impact Practices } \\
\text { Greek Life Membership } \\
\text { Sports Club Membership }\end{array}$ & $\begin{array}{l}.105 \\
.140 \\
- \\
\end{array}$ & $\begin{array}{l}.106 \\
.142 \\
-\end{array}$ & - \\
\hline \multicolumn{4}{|l|}{ Career Center } \\
\hline $\begin{array}{l}\text { Career Fairs } \\
\text { Advising } \\
\text { Class Presentations } \\
\text { Workshops }\end{array}$ & $\begin{array}{l}.063 \\
.030 \\
.075 \\
.054\end{array}$ & $\begin{array}{l}.067 \\
- \\
-013\end{array}$ & $\begin{array}{l}- \\
.076 \\
.176 \\
- \\
\end{array}$ \\
\hline \multicolumn{4}{|l|}{ Library } \\
\hline $\begin{array}{l}\text { Instruction } \\
\text { EZ Proxy } \\
\text { Study Room Reservations } \\
\text { Book Checkouts } \\
\text { Library Computer Logins }\end{array}$ & $\begin{array}{l}.066 \\
.008 \\
.001 \\
.005 \\
.001\end{array}$ & $\begin{array}{l}.062 \\
.008 \\
.001 \\
.005 \\
.001\end{array}$ & $\begin{array}{l}.123 \\
.014 \\
.003 \\
- \\
-\end{array}$ \\
\hline \multicolumn{4}{|c|}{ Univ Center for Academic Excellence } \\
\hline $\begin{array}{l}\text { Supplemental Instruction } \\
\text { Workshops } \\
\text { Classroom Presentations } \\
\text { Tutoring }\end{array}$ & $\begin{array}{l}.007 \\
.012 \\
- \\
.007\end{array}$ & $\begin{array}{l}.007 \\
- \\
-008\end{array}$ & $\begin{array}{l}.014 \\
- \\
- \\
-\end{array}$ \\
\hline
\end{tabular}




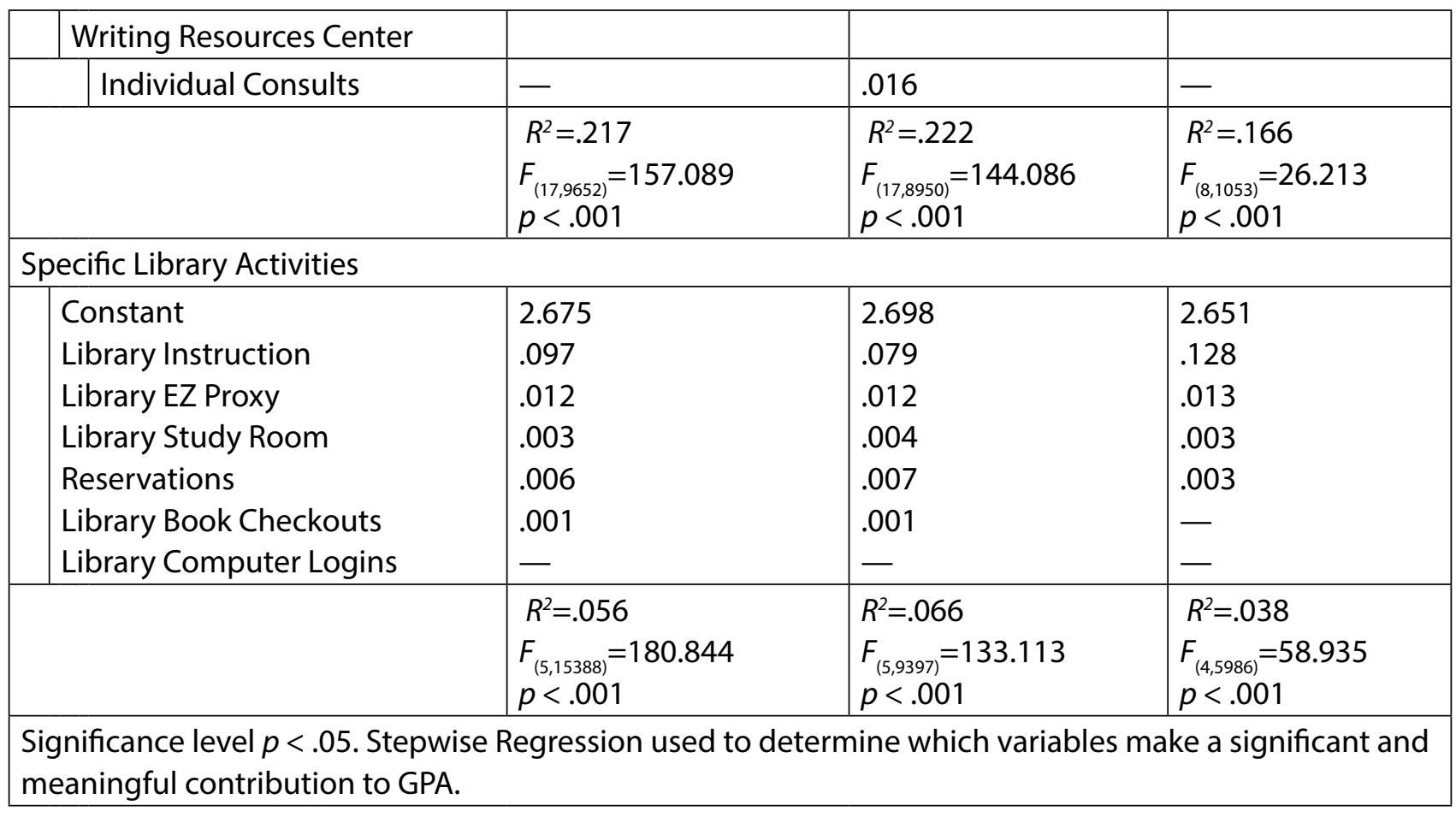




\begin{tabular}{|c|c|c|c|}
\hline \multicolumn{4}{|c|}{$\begin{array}{c}\text { TABLE B.2 } \\
\text { Four-Year Credit-Hour Completion Rates Significant Regression Models }\end{array}$} \\
\hline Independent Variable & Aggregate $(B)$ & $\begin{array}{l}\text { Entered as } \\
\text { Freshman }(B)\end{array}$ & $\begin{array}{l}\text { Entered as } \\
\text { Transfer }(B)\end{array}$ \\
\hline \multicolumn{4}{|l|}{ Total Engagements x Activity } \\
\hline Constant & .798 & .805 & .791 \\
\hline \multicolumn{4}{|l|}{ Student Affairs } \\
\hline $\begin{array}{l}\text { High-Impact Practices } \\
\text { Greek Life Membership }\end{array}$ & .026 & $\begin{array}{l}.023 \\
.042\end{array}$ & .036 \\
\hline \multicolumn{4}{|l|}{ Career Center } \\
\hline $\begin{array}{l}\text { Career Fairs } \\
\text { Advising } \\
\text { Class Presentations } \\
\text { Workshops }\end{array}$ & $\begin{array}{l}.020 \\
.007 \\
.026 \\
.012\end{array}$ & $\begin{array}{l}.019 \\
.007 \\
.023 \\
.015\end{array}$ & $\begin{array}{l}.022 \\
.007 \\
.034 \\
- \\
\end{array}$ \\
\hline \multicolumn{4}{|l|}{ Library } \\
\hline $\begin{array}{l}\text { Instruction } \\
\text { EZ Proxy } \\
\text { Study Room Reservations } \\
\text { Book Checkouts } \\
\text { Library Computer Logins }\end{array}$ & $\begin{array}{l}.016 \\
.002 \\
.0002 \\
.001 \\
.0001\end{array}$ & $\begin{array}{l}.011 \\
.002 \\
- \\
.001 \\
.0002\end{array}$ & $\begin{array}{l}.027 \\
.001 \\
- \\
- \\
-\end{array}$ \\
\hline \multicolumn{4}{|c|}{ University Center for Academic Excellence } \\
\hline $\begin{array}{l}\text { Supplemental Instruction } \\
\text { Tutoring }\end{array}$ & $\begin{array}{l}.002 \\
-\end{array}$ & .002 & $\begin{array}{l}.002 \\
-\end{array}$ \\
\hline & $\begin{array}{l}R^{2}=.069 \\
F_{(12,14517)}=89.784 \\
p<.001\end{array}$ & $\begin{array}{l}R^{2}=.085 \\
F_{(12,8910)}=68.579 \\
p<.001\end{array}$ & $\begin{array}{l}R^{2}=.045 \\
F_{(8,1053)}=32.981 \\
p<.001\end{array}$ \\
\hline \multicolumn{4}{|c|}{ Precollege/Demographic Variables x All Activities } \\
\hline Constant & .620 & .578 & .679 \\
\hline \multicolumn{4}{|l|}{ Precollege/Demographics } \\
\hline $\begin{array}{l}\text { HS GPA } \\
\text { ACT/SAT Standardized } \\
\text { Non UNCC Credits }\end{array}$ & $\begin{array}{l}.082 \\
-.005 \\
- \\
\end{array}$ & $\begin{array}{l}.087 \\
-.004 \\
.0004\end{array}$ & $\begin{array}{l}.076 \\
-.007 \\
- \\
\end{array}$ \\
\hline \multicolumn{4}{|l|}{ Student Affairs } \\
\hline $\begin{array}{l}\text { High-Impact Practices } \\
\text { Greek Life Membership } \\
\text { Sports Club Membership }\end{array}$ & $\begin{array}{l}.019 \\
.041 \\
-\end{array}$ & $\begin{array}{l}.020 \\
.041 \\
.015\end{array}$ & - \\
\hline \multicolumn{4}{|l|}{ Career Center } \\
\hline $\begin{array}{l}\text { Career Fairs } \\
\text { Advising } \\
\text { Class Presentations } \\
\text { Workshops }\end{array}$ & $\begin{array}{l}.017 \\
.006 \\
.024 \\
.012\end{array}$ & $\begin{array}{l}.017 \\
.006 \\
.023 \\
.012\end{array}$ & $\begin{array}{l}.015 \\
- \\
.053 \\
-\end{array}$ \\
\hline Library & & & \\
\hline
\end{tabular}




\begin{tabular}{|c|c|c|c|}
\hline $\begin{array}{l}\text { Instruction } \\
\text { EZ Proxy } \\
\text { Book Checkouts } \\
\text { Library Computer Logins }\end{array}$ & $\begin{array}{l}.011 \\
.001 \\
.001 \\
-\end{array}$ & $\begin{array}{l}.011 \\
.002 \\
.001 \\
.0002\end{array}$ & $\begin{array}{l}.025 \\
- \\
- \\
.0003\end{array}$ \\
\hline \multicolumn{4}{|c|}{ University Center for Academic Excellence } \\
\hline $\begin{array}{l}\text { Supplemental Instruction } \\
\text { Tutoring }\end{array}$ & $\begin{array}{l}.001 \\
.002\end{array}$ & $\begin{array}{l}.001 \\
.002\end{array}$ & - \\
\hline & $\begin{array}{l}R^{2}=.119 \\
F_{(14,9145)}=88.005 \\
p<.001\end{array}$ & $\begin{array}{l}R^{2}=.124 \\
F_{(16,8146)}=72.181 \\
p<.001\end{array}$ & $\begin{array}{l}R^{2}=.075 \\
F_{(6,990)}=13.378 \\
p<.001\end{array}$ \\
\hline \multicolumn{4}{|l|}{ Specific Library Activities } \\
\hline $\begin{array}{l}\text { Constant } \\
\text { Library Instruction } \\
\text { Library EZ Proxy } \\
\text { Library Study Room Reservations } \\
\text { Library Book Checkouts } \\
\text { Library Computer Logins }\end{array}$ & $\begin{array}{l}.821 \\
.020 \\
.002 \\
.0005 \\
.001 \\
.0003\end{array}$ & $\begin{array}{l}.832 \\
.015 \\
.002 \\
.0005 \\
.001 \\
.0003\end{array}$ & $\begin{array}{l}.808 \\
.028 \\
.001 \\
.0004 \\
- \\
.0002\end{array}$ \\
\hline & $\begin{array}{l}R^{2}=.031 \\
F_{(5,14524)}=93.102 \\
p<.001\end{array}$ & $\begin{array}{l}R^{2}=.035 \\
F_{(5,9397)}=63.728 \\
p<.001\end{array}$ & $\begin{array}{l}R^{2}=.021 \\
F_{(4,5602)}=30.652 \\
p<.001\end{array}$ \\
\hline
\end{tabular}

Significance level $p<.05$. Stepwise Regression used to determine which variables make a significant and meaningful contribution to GPA.

\section{Notes}

1. National Center for Education Statistics, Fast Facts, prepared by Institute of Education Sciences (Washington, DC: US Department of Education, 2018), available online at nces.ed.gov/fastfacts/display.asp?id=40 [accessed 30 July 2019].

2. Vincent Tinto, Leaving College: Rethinking the Causes and Cures of Student Attrition, 2nd ed. (Chicago, IL: University of Chicago Press, 1993); Vincent Tinto and Brian Pusser, Moving from Theory to Action: Building a Model of Institutional Action for Student Success (Washington, DC: NPEC, 2006).

3. George D. Kuh, Ken O'Donnell, and Sally Reed, Ensuring Quality and Taking High-Impact Practices to Scale (Washington, DC: Association of American Colleges and Universities, 2013).

4. Association of College and Research Libraries (ACRL), Academic Library Impact: Improving Practice and Essential Areas to Research, prepared by Lynn Silipigni Connaway, William Harvey, Vanessa Kitzie, and Stephanie Mikitish (Chicago, IL: ACRL, 2017), available online at www.ala.org/acrl/sites/ala.org.acrl/files/content/publications/ whitepapers/academiclib.pdf [accessed 30 July 2019].

5. Anne Cooper Moore and Rebecca Croxton, "From Matriculation to Graduation: A University-wide Assessment of Student Engagement and Success" (presentation at the Assessment Institute in Indianapolis, IN, October 21-23, 2018), available online at assessmentinstitute.iupui.edu/ [accessed 30 July 2019].

6. The University of North Carolina System, "UNC InfoCenter," available online at www.northcarolina. edu/infocenter\#interactiveData [accessed 31 July 2019].

7. The University of North Carolina at Charlotte, "About Us," available online at https://www.uncc.edu/ landing/about-us [accessed 31 July 2019].

8. Rebecca Croxton and Anne Cooper Moore, "Quantifying the Value of the Academic Library" (paper presented at the 2018 ARL Assessment Conference, Houston, TX, December 5-7, 2018), available online at libraryassessment.org/ [accessed 30 July 2019].

9. Rebecca Croxton and Anne Cooper Moore, "From Matriculation to Graduation: Alignment of Library Data with University Metrics to Quantify Library Value" (paper presented at the ACRL 2019 Annual Conference, Cleveland, OH, April 10-13, 2019), available online at conference.acrl.org/ [accessed 30 July 2019]. 
10. Deborah Goodall and David Pattern, "Academic Library Non/Low Use and Undergraduate Student Achievement: A Preliminary Report of Research in Progress," Library Management 111, no. 32 (2011): 159-70; Krista M. Soria, "Factors Predicting the Importance of Libraries and Research Activities for Undergraduates," Journal of Academic Librarianship 39, no. 6 (2013): 464-70; Krista M. Soria, Jan Fransen, and Shane Nackerud, "Library Use and Undergraduate Student Outcomes: New Evidence for Students' Retention and Academic Success," portal: Libraries \& The Academy 13 (2013): 147-64; Krista M. Soria, Jan Fransen, and Shane Nackerud, "Stacks, Serials, Search Engines, and Students' Success: First-Year Undergraduate Students' Library Use, Academic Achievement, and Retention," Journal of Academic Librarianship 40 (2014): 84-91; Krista M. Soria, Jan Fransen, and Shane Nackerud, "Beyond Books: The Extended Academic Benefits of Library Use for First-Year College Students," College of Research Libraries 78 (2017): 8-22; Krista M. Soria, Jan Fransen, and Shane Nackerud, "The Impact of Academic Library Resources on Undergraduates' Degree Completion," College \& Research Libraries 78 (2017): 812-23.

11. Goodall and Pattern, "Academic Library Non/Low Use and Undergraduate Student Achievement," 159-70.

12. Shuh Han Rebekah Wong and T.D. Webb, "Uncovering Meaningful Correlation between Student Academic Performance and Library Material Usage," College \& Research Libraries 72 (2011): 361-70.

13. Ula Gaha, Suzanne Hinnefeld, and Catherine Pellegrino, "The Academic Library's Contribution to Student Success: Library Instruction and GPA," College \& Research Libraries 79, no. 6 (2018): 737-45; Greater Western Library Alliance (GWLA), The Impact of Information Literacy Instruction on Student Success: A Multi-institutional Investigation and Analysis, prepared by Joni Blake, Melissa Bowles-Terry, Shirlene Pearson, and Zoltan Szentkiralyi (Prairie Village, KS: Greater Western Library Alliance, 2017), available online at scholar.smu.edu/cgi/viewcontent.cgi?a rticle=1015\&context=libraries_cul_research [accessed 30 July 2019]; Soria, Fransen, and Nackerud, “Library Use and Undergraduate Student Outcomes," 147-64.

14. Gaha, Hinnefeld, and Pellegrino, "The Academic Library's Contribution to Student Success," 737-45.

15. GWLA, The Impact of Information Literacy Instruction on Student Success.

16. Soria, Fransen, and Nackerud, "Library Use and Undergraduate Student Outcomes," 147-64; Soria, Fransen, and Nackerud, "Stacks, Serials, Search Engines, and Students' Success," 84-91; Soria, Fransen, and Nackerud, "Beyond Books," 8-22; Soria, Fransen, and Nackerud, "The Impact of Academic Library Resources on Undergraduates' Degree Completion," 812-23.

17. Soria, Fransen, and Nackerud, "Beyond Books," 8-22; Soria, Fransen, and Nackerud, "The Impact of Library Resources on Undergraduates' Degree Completion," 812-23; Krista M. Soria et al., "The Impact of Academic Library Resources on First-Year Students' Learning Outcomes," Research Library Issues, 29 (2017): 5-20.

18. Soria, Fransen, and Nackerud, "Beyond Books," 8-22; Soria, Fransen, and Nackerud, "The Impact of Library Resources on Undergraduates' Degree Completion," 812-23.

19. Soria, Fransen, and Nackerud, "Beyond Books," 8-22; Soria, Fransen, and Nackerud, "The Impact of Library Resources on Undergraduates' Degree Completion," 812-23.

20. "ALA Code of Ethics," American Librarian Association, last modified January 22, 2008, available online at www.ala.org/tools/ethics [accessed 26 July 2019].

21. Association of College \& Research Libraries (ACRL), Value of Academic Libraries: A Comprehensive Research Review and Report, researched by Megan Oakleaf (Chicago, IL: ACRL, 2010), available online at www.acrl.ala. org/value/?page_id=21 [accessed 26 July 2019].

22. NISO, NISO Consensus Principles on User's Digital Privacy in Library, Publisher, and Software-Provided Systems (NISO Privacy Principles), prepared by the National Information Standards Organization (Baltimore, DC: NISO, 2015), available online at www.niso.org/publications/privacy-principles [accessed 26 July 2019]; Niall Sclater and Paul Bailey, Code of Practice for Learning Analytics (Belfast, Ireland: JISC, 2018), available online at www.jisc.ac.uk/ guides/code-of-practice-for-learning-analytics [accessed 26 Jul 2019].

23. Kristin A. Briney, "Data Management Practices in Academic Library Learning Analytics: A Critical Review," JLSC 7 (2019): 1-39.

24. Briney, "Data Management Practices in Academic Library Learning Analytics," 1-39; NISO, NISO Consensus Principles on User's Digital Privacy in Library, Publisher, and Software-Provided Systems (NISO Privacy Principles); Sclater and Bailey, Code of Practice for Learning Analytics.

25. Giselle Bonet and Barbara R. Walters, "High Impact Practices: Student Engagement and Retention," College Student Journal 50, no. 2 (2016): 224-35.

26. Eric Kelderman, "With State Support Now Tied to Completion, Tennessee Colleges Must Refocus," Chronicle of Higher Education 59, no. 6 (2012): A16-A18.

27. W. Paul Vogt and R. Burke Johnson, Dictionary of Statistics \& Methodology: A Nontechnical Guide for the Social S, 4th ed. (Los Angeles, CA: Sage, 2011).

28. Franz Faul et al., "Statistical Power Analyses Using G*Power 3.1: Tests for Correlation and Regression Analyses," Behavior Research Methods 41, no. 4, 1149-60. 
29. NISO, NISO Consensus Principles on User's Digital Privacy in Library, Publisher, and Software-Provided Systems (NISO Privacy Principles); Sclater and Bailey, Code of Practice for Learning Analytics.

30. Tinto, Leaving College.

31. Briney, "Data Management Practices in Academic Library Learning Analytics," 1-39; NISO, NISO Consensus Principles on User's Digital Privacy in Library, Publisher, and Software-Provided Systems (NISO Privacy Principles); Sclater and Bailey, Code of Practice for Learning Analytics. 